\author{
DOSSIÊ \\ TRIBUNAL DO SANTO OFÍCIO PORTUGUÊS, 200 ANOS APÓS EXTINÇÃO: \\ HISTÓRIA E HISTORIOGRAFIA
}

\title{
MULHERES AFRICANAS NAS REDES DOS AGENTES DA INQUISIÇAO DE LISBOA: O CASO DE CRISPINA PERES, EM CACHEU, SÉCULO XVII*
}

\author{
AFRICAN WOMEN IN THE NETWORKS OF THE LISBON INQUISITION: \\ CRISPINA PERES OF CACHEU IN THE 17'TH CENTURY
}

Vanicléia Silva Santos**

\begin{abstract}
RESUMO
O objetivo deste texto é discutir a trajetória de Crispina Peres, proeminente comerciante de Cacheu que foi demonizada por membros dessa comunidade mercantil no contexto de comércio de seres humanos, em meados do século XVII. Por meio de uma análise detalhada dos testemunhos que constam no processo inquisitorial movido contra Crispina, mostro que o Tribunal do Santo Ofício português foi utilizado pelos seus agentes e pela elite local para eliminar inimigos e concorrentes comerciais. O argumento central deste texto é que o estado de viuvez. e o sucesso econômico propiciava mais mobilidade para as mulheres livres de Cacheu tocarem seus negócios e fortalecia suas casas comerciais, sem obrigaçôes com regimes patriarcais e patrilineares. Contudo, a mobilidade das viúvas as colocava em posição de vulnerabilidade perante seus concorrentes comerciais portugueses ou nascidos localmente, bem como levava a comunidade a demonizar os meios utilizados por elas para obterem enriquecimentos.
\end{abstract}

PALAVRAS-CHAVE: Cacheu. Inquisição de Lisboa. Crispina Peres. Tráfico de Escravos. Vulnerabilidade.

\begin{abstract}
This text discusses the life of Crispina Peres, a prominent merchant from Cacheu, and her conflicts with members of this mercantile community during the acceleration of the commerce of human beings in the mid-17th century. Through a detailed analysis of the testimonies in the inquisitorial process filed against Crispina, I show that Inquisition agents and the local elite used the Portuguese Holy Office in a conspiracy to eliminate enemies and commercial competitors. The central argument of this text is that the state of widowhood and economic success provided more mobility for the free women of Cacheu to run their businesses and strengthen their commercial houses without obligations to patriarchal regimes. However, the mobility of widows placed them in a vulnerable position. Various segments of the community, including the Portuguese, locally born authorities and commercial competitors, households, and the enslaved all demonized the wealthy African women. Often various groups in the community raised suspicion about how these women obtained their wealth.
\end{abstract}

KEYWORDS: Cacheu. African City. Portuguese Inquisition. Crispina Peres. Slave Trade. Vulnerability.

\footnotetext{
* Uma versão preliminar deste artigo foi apresentada no painel "What About Widows?, Part II: Slavery, Inheritance, \& SlaveTrading Widow", no The African Studies Association 2020 Virtual Annual Meeting, em 20 de novembro de 2020. Sou grata a Mariana Candido (Emory University) pelo convite e aos comentários dos participantes. Agradeço também ao pessoal do Grupo de pesquisas Áfricas (CNPq/UFMG) e demais colegas que leram este texto e trouxeram importantes contribuições.

** Curadora da Coleção Africana do Penn Museum da University of Pennsylvania. Professora licenciada da Universidade Federal de Minas Gerais (UFMG). Doutorado em História Social pela Universidade de São Paulo (USP). Email: vanijacobina@gmail.com
} 


\section{INTRODUÇÃO}

O Tribunal do Santo Ofício foi utilizado largamente por seus agentes para punir pessoas, não apenas por questões de ordem religiosa, mas também política e econômica. Em 1661, vindo de Cabo Verde, desembarcou em Cacheu o capuchinho Paulo de Lordelo, nomeado Comissário do Santo Ofício da Inquisição de Lisboa para apurar as denúncias que chegaram à Inquisição de Lisboa. O frei ficou hospedado na fortaleza da vila. Ele chegou para investigar as denúncias contra os padres Luiz Roiz e Antônio Vaz, acusados de praticarem sodomia e de viverem amancebados. Contudo, as investigações do comissário abriram a oportunidade para que pessoas pudessem se vingar de vizinhos e se livrarem de pessoas indesejadas na sociedade.

Quatro anos depois, em janeiro de 1665, uma força tarefa foi arquitetada para prender a mulher mais poderosa em Cacheu, povoação estabelecida nas margens do Rio Cacheu (ou São Domingos), próxima ao Oceano Atlântico. As autoridades locais incumbidas da prisão de Crispina Peres cumpriam ordens enviadas pela Inquisição de Lisboa. Por que Crispina Peres, viúva e casada pela segunda vez, com cerca de 50 anos de idade, foi perseguida e presa pela Inquisição de Lisboa? O objetivo deste texto não é discutir as ações persecutórias do tribunal inquisitorial português, mas a trajetória de Crispina Peres, uma proeminente comerciante que foi demonizada pelas autoridades portuguesas e pela comunidade mercantil de Cacheu por causa de seu destaque social e econômico, no contexto de comércio de seres humanos, em meados do século XVII.

O texto está organizado em três partes. A primeira discute o pertencimento de Crispina Peres a uma linhagem de mulheres comerciantes na região do rio Cacheu. Elas se associaram aos europeus instalados na costa, incrementaram seus negócios internos e ganharam liderança política na comunidade. A segunda parte revela aspectos importantes da vida social de Peres em Cacheu, seu status de católica, seus casamentos, heranças e propriedades. A última analisa o processo de demonização de Crispina Peres, que começou após sua primeira viuvez. A demonização de Crispina Peres foi uma estratégia utilizada pela comunidade mercantil de Cacheu para banir a influência comercial e política de sua família. Esta foi a mesma estratégia para prender, pouco tempo depois, outra poderosa comerciante de Cacheu, Bibiana Vaz Gomes. O argumento central deste texto é que o estado de viuvez propiciava mais liberdade para as mulheres livres de Cacheu tocarem seus negócios e fortalecerem suas casas comerciais, sem obrigações com regimes patriarcais e patrilineares. A liberdade das viúvas levava a comunidade a demonizar os meios utilizados por elas para obterem enriquecimentos.

\section{Fontes}

As fontes utilizadas neste texto são relatos de viajantes e o processo inquisitorial contra Crispina Peres. As fontes seiscentistas são abundantes em informações sobre a atuação das mulheres no processo de exploração do comércio na costa ocidental africana, juntamente aos europeus; sobre o protagonismo 
das mulheres no comércio de curta e longa distância; e sobre o papel delas para o comércio transatlântico, bem como a presença delas em torno de questões comerciais e políticas. Contudo, a história das mulheres na região ao sul do Gâmbia e da participação ativa delas naquelas sociedades foi silenciada pelas narrativas muçulmanas, assim como pelas narrativas europeias (BIVAR, 2018). As mulheres foram sucessivamente ignoradas nos relatos produzidos pelos exploradores, viajantes, missionários etc.; ou foram descritas negativamente como traiçoeiras ou interesseiras. O fato é que, de uma forma ou de outra, as mulheres estão presentes nas mais diversas fontes produzidas por estrangeiros ou pessoas da região. Assim, é necessário utilizar metodologia apropriada para identificar suas ações nas entrelinhas dos textos e, também, questionar sobre a ausência das mulheres.

Um processo inquisitorial é a principal fonte deste ensaio. Este processo teve início com uma devassa instruída em Cacheu, em 1656, pelas autoridades religiosas locais e depois remetida para a Inquisição de Lisboa. ${ }^{1} \mathrm{O}$ documento continha denúncia contra várias pessoas, entretanto os inquisidores acataram apenas a denúncia contra Crispina Peres "pella culpa de usar feitiçarias e gentilidades". O documento tem cerca de 400 páginas e contém informações inéditas sobre o microcosmo social de Cacheu e suas conexões com o mundo Atlântico. O registro da genealogia de Crispina Peres e o detalhamento da vida de mais de 100 pessoas que faziam parte de sua rede possibilitam a escrita de uma micro-história (LEPORE, 2001; LINDSAY, 2017) de Cacheu e das pessoas que lá viviam e de suas relações com o mundo Atlântico no início da Era Moderna. O processo inquisitorial do Santo Ofício português contra Crispina Peres oferece a oportunidade rara de acessar a narrativa de uma mulher africana livre. Esta fonte, pela riqueza de detalhes que carrega, permite desconstruir categorias sociais e dicotomias criadas pela historiografia sobre o papel de mulheres $x$ homens na África Ocidental, negros $x$ brancos, europeus $x$ africanos, luso-africanas $\mathrm{x}$ africanas, colonização europeia $x$ exploração de africanos.

No amplo conjunto de documentos jurídicos portugueses incluem-se processos-crime, processos inquisitoriais, depoimentos, ações judiciais, devassas etc. Dentro da variedade de documentos produzidos pelo Santo Ofício da Inquisição de Portugal, entre 1536 e 1821 (respectivamente, anos de fundação e extinção), os processos inquisitoriais são os mais usados por historiadoras e historiadores. Estes processos são polifônicos, pois depoimentos eram tomados in loco por agentes religiosos apoiados por civis, os quais, em geral, faziam parte das redes de micropoderes locais. No caso da Guiné, processos foram iniciados por pessoas que não pertenciam oficialmente à estrutura da inquisição, como fizeram os padres visitadores que realizavam as visitas pastorais na região da Guiné. De acordo com a legislação episcopal, as devassas feitas durante as visitas pastorais também tinham como objetivo desterrar os escândalos e as denúncias. A partir disso, os religiosos encaminhavam as denúncias para a Inquisição. Ou seja, na construção de uma denúncia havia o envolvimento da população em geral. Além disso, os

\footnotetext{
${ }^{1}$ Arquivo Nacional da Torre do Tombo, Tribunal do Santo Ofício, Inquisição de Lisboa [doravante ANTT, TSO, IL], Processo 2079 (1668).
} 
dialogismos desta documentação, ao mesmo tempo que expressavam vozes sociais, também expressavam assimetrias entre estas vozes.

O Santo Ofício Português agiu na Costa Ocidental Africana (SILVA, 2002; SILVA, 2004) por meio das autoridades civis locais e portuguesas, de religiosos cabo-verdianos e, também, de clérigos europeus em missão em Cabo Verde e nas partes da Guiné. ${ }^{2}$ Em comparação com o Brasil, os tentáculos do Santo Ofício português tiveram curto alcance na costa Atlântica, especialmente na Guiné. A razão disto era o poder das autoridades africanas somado à fraca presença de autoridades portuguesas, que não controlavam nem o comércio transatlântico que a Coroa desejava monopolizar. Contudo, os braços do Santo Ofício alcançaram algumas pessoas nascidas localmente, como Crispina Peres. Isso indica que a alta posição social desta mulher, sua condição de cor, o teor das acusações (feitiçaria e gentilismo) e, principalmente o perfil dos denunciantes, que eram em sua maioria homens revestidos de autoridades locais, comerciantes e marinheiros, contribuíram fortemente para que os inquisidores de Lisboa aceitassem a denúncia contra ela. A devassa contra Crispina Peres foi enviada pelas autoridades estabelecidas na costa da Guiné para os inquisidores de Lisboa, os quais deram prosseguimento ao processo que culminou em conluios de inimigos, sua prisão, julgamento e condenação.

\section{Visão geral e problemática}

Estudos sobre o comércio entre os rios Casamance e Serra Leoa estiveram concentrados na atuação dos homens europeus e seus descendentes. Tais estudos tendiam a ver as mulheres desta região como "sócias" e "concubinas" (HAVIK, 1997), isto é, intermediárias culturais ou assistentes dos referidos homens. Elas eram vistas equivocadamente como aquelas que cuidavam e providenciavam comida, remédios e curandeiros para doenças de seus maridos, além de outras atividades esperadas de uma esposa, e que também atuavam como parceiras comerciais deles, conforme interpretou George Brooks (2003, p. 125), eivado por seu filtro cultural ocidental e masculino.

\footnotetext{
2 O Santo Ofício da Inquisição dos Reinos de Portugal foi instituído em 1536 e possuía três tribunais: Coimbra, Évora e Lisboa. As regiões atlânticas sob administração de Portugal estavam sob jurisdição da Inquisição de Lisboa. O único espaço do atlântico que recebeu Visitador do Santo Ofício foi o Brasil. O único tribunal da Inquisição fora de Portugal foi o de Goa, na Índia. Em Cacheu e Cabo Verde, a atuação do Tribunal de Lisboa foi realizada por meio de agente habilitados pelo Santo Ofício. A rede de comissários e familiares estava articulada entre o Santo Ofício da Inquisição de Lisboa e a justiça eclesiástica e civil existentes na Guiné e Cabo Verde. As denúncias feitas por autoridades religiosas e civis eram elementos centrais para que as autoridades religiosas tomassem conhecimento dos acontecimentos. Identificamos algumas ações de autoridades da Guiné solicitando a presença de agentes do Santo Ofício na costa. Em 1623, uma carta régia enviada ao Bispo de Cabo Verde solicitava a nomeação de um religioso como comissário do Santo Ofício: "E porque no dito porto de Cacheu e nos mais daquella Costa há muyta gente da naçaõ dos christaõs nouos, e que viuem com muita dissuluçaõ, deue V. Magestade ser seruido mandar ao Inquisidor Geral que nomee por Comissário do Santo Officio a hum dos Relegiosos da Companhia que lá ouuerem de residir" (BRÁSIO, 1979, p. 11). No mesmo ano, o monarca escreveu ao Bispo Dom Fernão M. Mascarenhas, Inquisidor geral de Portugal para tratar sobre a necessidade de nomear um comissário do Santo Ofício para aquela parte. O bispo concordou com o pedido do Rei. Mas só se tem notícia de um familiar habilitado para a Guiné (Paulo Barradas da Silva), quase vinte anos depois, em 1642. Em 1658, o franciscano Frei Paulo de Lordello (superior do convento de São Francisco da Piedade na cidade de Ribeira Grande, Cabo Verde), foi o primeiro comissário do Santo Ofício habilitado para a Guiné. Pero Paes e Sebastiam Sam Vicente, também franciscanos, eram os escrivães. Lordello chegou em Cacheu apenas em 01 de janeiro de 1661 e morreu três anos depois. Com a morte do padre Lordello, o frade André de Faro assumiu o posto de Comissário do Santo Ofício, em 1665, e deu prosseguimento ao processo contra Crispina Peres.
} 
Esta perspectiva da feminilidade ocidental transferida para o Oeste da África está sendo modificada por estudos concentrados em evidenciar a participação dessas mulheres em várias esferas do mundo social onde viviam. Processos históricos só podem ser compreendidos adequadamente quando indivíduos são situados em seus contextos sociais. Assim, as mulheres da Guiné devem ser compreendidas/analisadas como sujeitos históricos em seus contextos locais e regionais, em termos de seus pertencimentos raciais e sociais. Estes componentes da interseccionalidade devem ser levados em consideração porque as fontes foram produzidas, em geral, por homens europeus ou mestiços, que pensavam a partir de um ponto de vista europeu. Portanto, as perspectivas sobre a feminilidade dos viajantes eram pautadas pelo modelo da mulher portuguesa, cujas atividades estavam principalmente reservadas ao âmbito doméstico.

A recente coletânea African women in the Atlantic world traz vários exemplos de mulheres de diversas sociedades da costa Atlântica que aproveitaram as "oportunidades oferecidas pelo comércio Atlântico e o relacionamento com homens europeus para negociar suas posições social e econômica" (CANDIDO; JONES, 2019, p. 2; SILVA-SANTOS, 2021). Um ponto transversal, que perpassa toda a obra, organizada por Mariana Candido e Adam Jones, é a questão da vulnerabilidade das mulheres proprietárias. Embora as mulheres fossem maioria em grande parte das sociedades afro-atlânticas, a violência e a insegurança eram constantes em suas vidas. Por trás das extraordinárias histórias de mulheres que conseguiram prosperidade e mobilidade havia também um ambiente de vulnerabilidade que as acompanhava. Além das referências de pesquisas realizadas no exterior sobre mulheres africanas residentes na costa da África Ocidental, este artigo também se beneficia do diálogo com a historiografia brasileira que trata de biografias e micro-histórias de pessoas africanas e seus descendentes (MOTT, 1993; MOTT, 1994; FURTADO, 2003; REIS, 2006; PARES; CASTILLO, 2007; REIS, 2010; RANGEL, 2012; REIS, 2014; FONSECA, 2015; MARCUSSI, 2015; REGINALDO, 2015; MAIA, 2016; OLIVEIRA, 2018; SCHERER; WEIMER, 2021; CANDIDO, 2017; CHAGAS, 2021).

As comerciantes do Senegal, especialmente aquelas situadas em St. Louis e Ilha de Gorée (BROOKS, 1976; JONES, 2019), são as mais estudadas na região da Senegâmbia. ${ }^{3}$ Pesquisas mais recentes sobre mulheres do Oeste Africano têm refutado a perspectiva ultrapassada, que interpretava as mulheres africanas instaladas na costa como meras assistentes dos homens europeus. Estes novos estudos têm focado na ação de comerciantes africanas do início da Era Moderna como protagonistas da história com poderes políticos e econômicos, tais como Bibiana Vaz (RODNEY, 1970; HAVIK, 2004; HAVIK, 2012;), Esperança ou Hope Booker, Bilinguere (KRIGER, 2019), Madame Watts, Aquassiba, Betje e Catrijn (EVERTS, 2019), Anne Rossignol (SEMLEY, 2019) e outras. Até então, nenhum trabalho

\footnotetext{
3 Senegâmbia não é um conceito histórico, mas uma criação da historiografia contemporânea. Para o historiador Boubacar Barry, a Senegâmbia compreende o território delimitado pelo rio Senegal (norte), o rio Kolonté (sul), o oceano Atlântico (leste) e o Futa Toro e o Futa Djalon (oeste), que era marcado pela presença do Islã. Por outro lado, José da Silva Horta e Eduardo Costa Dias sugerem que os limites indicados por Barry para a Senegâmbia sejam ampliados ao sul, até a região de Serra Leoa, pois consideram que a referida região fazia parte de um espaço comercial, político, social e cultural em comum, com funcionamento articulado, isto é, um espaço de "conveniência e convivência" e "complementaridade e transição" (BARRY, 2002; DIAS; HORTA, 2007).
} 
realçou a trajetória da comerciante Crispina Peres, que faz parte das primeiras gerações de mulheres guineenses que se casaram e associaram-se aos comerciantes europeus, lançados, tangomãos e grumetes no período da expansão do tráfico transatlântico de escravizados. Portanto, este trabalho foca na excepcionalidade da micro-história de Crispina Peres e sua experiência durante a emergência do tráfico transatlântico de escravizados e de diversos produtos desta região.

\section{INTERAÇÕES ENTRE MULHERES DE CACHEU E EUROPEUS NO INÍCIO DO SÉCULO XVII}

As uniões maritais entre as mulheres de Cacheu com europeus e seus descendentes faziam parte de complexas relações que envolviam, naturalmente, afinidades amorosas, formação de famílias, bem como compreendiam processos de sucesso social e econômico de homens e mulheres na costa da atual Guiné. Começo destacando este aspecto porque o casamento como mecanismo de ascensão social e de arranjos políticos era bastante comum ou natural entre as elites europeias; portanto, não era diferente na costa ocidental africana (OLIVEIRA, 2019).

Crispina Peres nasceu no contexto de expansão dos negócios europeus ao Sul do rio Gâmbia. Europeus aproveitaram-se de pontos estratégicos das redes inter-regionais de comércio criadas pelos africanos para implantar feitorias que passaram a funcionar como plataformas para o mundo Atlântico. Estes homens se casaram com filhas de governantes, muitas delas ligadas às linhas mercantis interregionais, como foi o caso de Crispina Peres, filha de Isabel Pessoa e de Rodrigo Peres Baltazar. A mãe e avós maternos de Crispina eram Banhuns, naturais de Guinguim (atual Beguingue). Guinguim está localizado ao norte de Cacheu, próximo ao porto de Buguendo, em São Domingos, outro importante entreposto comercial, que era controlado pelos povos Banhuns. O pai de Crispina Peres era Rodrigo Peres Baltazar, natural da Ilha Terceira, comerciante estrangeiro que fazia negócios em Guinguim (Cf. Figura 1). 
Figura 1 - Detalhe da região de Cacheu e outros da Guiné

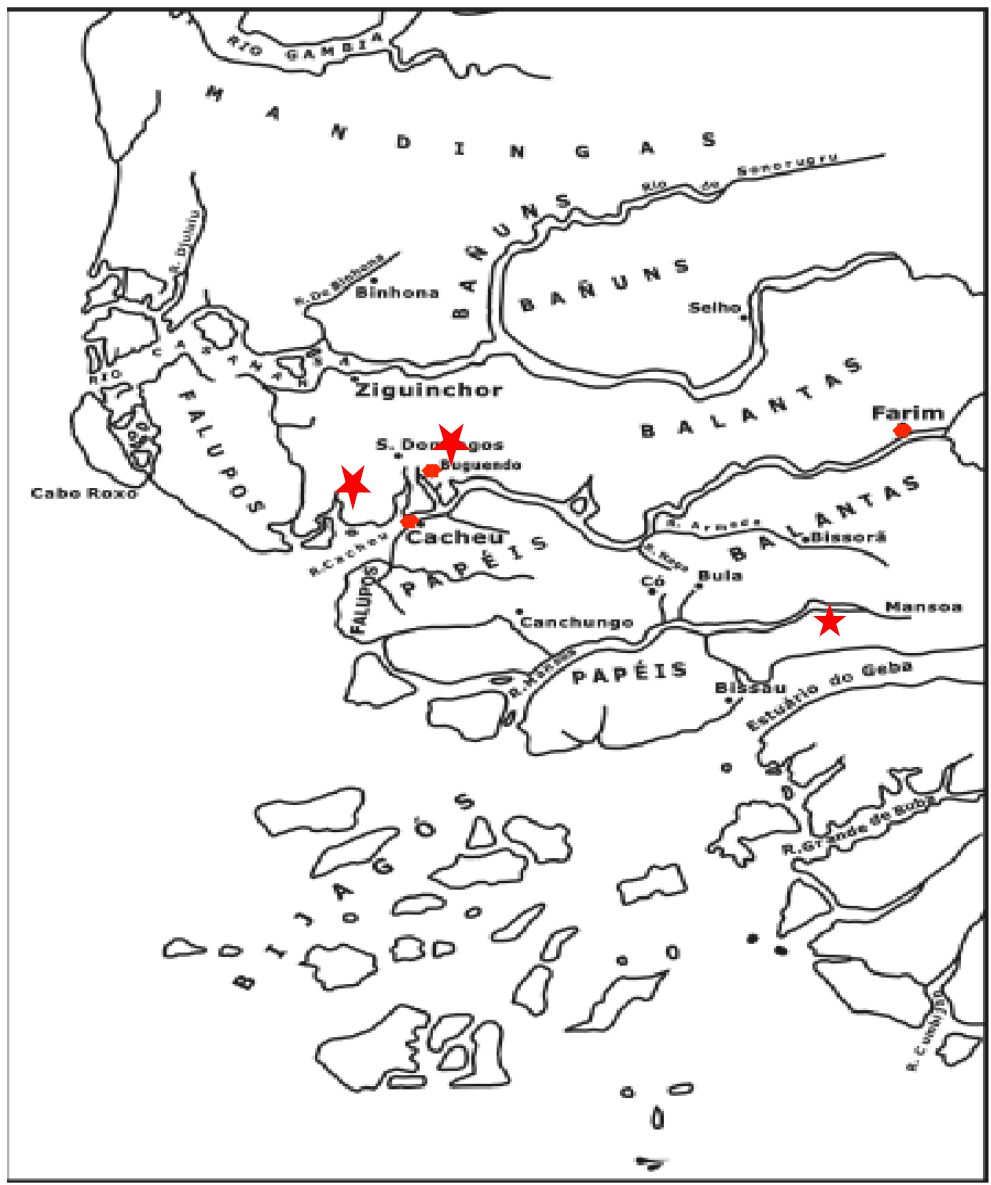

Fonte: CARREIRA (1964, p. 236). Destaque nosso para os locais de nascimento de Crispina Peres, Jorge Gonçalves e os avós maternos dela.

Rodrigo Peres Baltazar conheceu Isabel Pessoa em Guinguim, onde se casaram, e depois foram morar em Geba, onde Crispina nasceu. Quando Crispina já era adolescente, os pais se mudaram para Cacheu. Mais tarde, depois que ela já era casada, eles foram morar em Farim. Sobre os avós paternos de Crispina Peres, ela informou que não se lembrava dos nomes deles. Certamente seu avô paterno era da Ilha Terceira também, e suspeito que sua avó paterna era da Guiné. Neste sentido, Crispina Peres pertencia a uma linhagem de mulheres comerciantes da região do Rio São Domingos. Por meio da documentação inquisitorial, conseguimos obter informações inéditas sobre três gerações de mulheres da mesma familia, comerciantes e residentes nos principais portos da região: Guinguim, Farim, Cacheu e Geba (Figura 2). 
Figura 2 - Árvore da Família de Crispina Peres e Jorge Gonçalves Francês, séculos XVI-XVII.

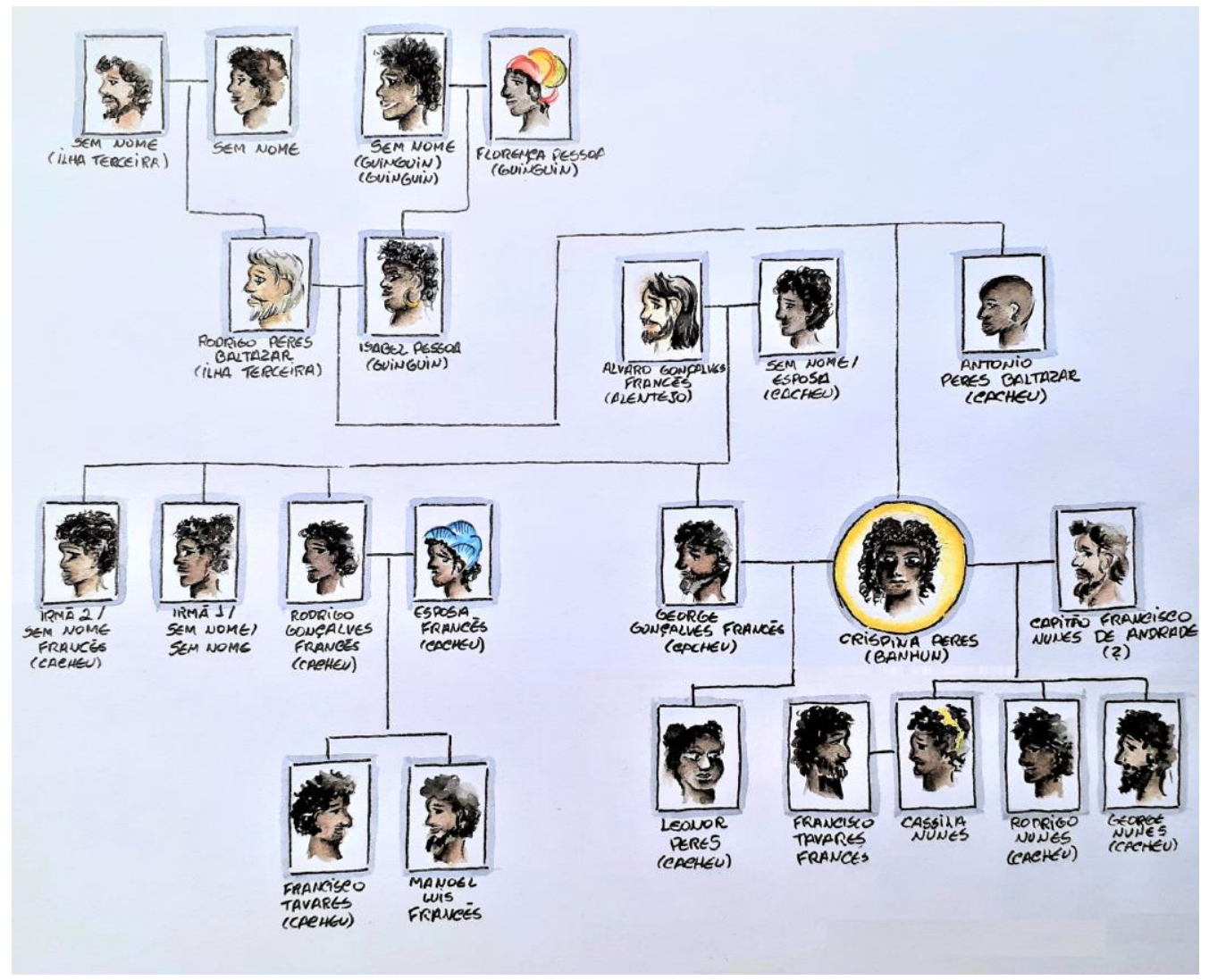

Fonte: Aquarela de Felipe Augusto B. Rangel sobre Gráfico elaborado pela autora com base em ANTT, TSO, IL, Processo 2079 (1668).

O pai do segundo marido de Crispina Peres era Álvaro Gonçalves Francês, natural do Alentejo. ${ }^{4}$ No final do século XVI, Álvaro Gonçalves Francês se casou com uma mulher de Cacheu, mas seu nome não foi anotado pelas autoridades. Este casal teve quatro crianças: Jorge Gonçalves Francês, Rodrigo Gonçalves Francês e duas filhas, que não tiveram seus nomes mencionados na documentação. Assim, três mulheres, Isabel Pessoa (mãe de Crispina Peres), Crispina Peres e a mãe de seu segundo marido,

\footnotetext{
${ }^{4}$ Álvaro Gonçalves Francês, o pai de Jorge Gonçalves Francês (segundo sogro de Crispina Peres) deve ter chegado na região da Guiné no início de 1600, pois, em 1616, ele já fazia negócios com Manoel Batista Peres, comerciante português que vivia em Lima-Peru, o qual passou um ano (1616-17) em Cacheu fazendo negócios e registrou o nome de Álvaro Gonçalves Francês em seu caderno de contas (NEWSON, 2013, p. 257-282). Em 1635, Álvaro Gonçalves Francês tornou-se capitãomor de Cacheu. Contudo, o ouvidor-geral e provedor da Fazenda Real da ilha de Santiago de Cabo Verde, mandou prender e sequestrar os bens dele, onde tinha fazendas porque fazia trato comercial com os holandeses, ingleses e franceses. Álvaro Gonçalves Francês morreu em 1646. Arquivo Histórico Ultramarino, Guiné (doravante AHU - Guiné), cx. 1, doc. 20 e $12 /$ [ant. 1635, Setembro, 24, Santiago] Requerimento do ouvidor-geral e provedor da Fazenda Real da ilha de Santiago de Cabo Verde, capitão Dinis Eanes da Fonseca, ao rei [D. Filipe III] solicitando pagamento pelas diligências dele e dos capitães Domingos Lobo Reimão, Francisco Pereira, que morreu de peçonha, Paulo Barradas da Silva, o feitor e recebedor da Fazenda Real Paulo Gomes e o escrivão João Correia da Silva, para prender e sequestro dos bens de Álvaro Gonçalves, francês, morador em Cacheu, onde tinha fazendas e trato com os holandeses, ingleses e franceses, em cumprimento das ordens do governador de Santiago, Frei Cristóvão Cabral, até que lhe fora comunicada a anulação da ordem de prisão e de embargo, devido ao perdão concedido ao foragido. Obs.: m. est.; anexo certidões. AHU-Guiné, cx. 1, doc. 20 e 12. AHU_CU_049, Cx. 1, D. 15.
} 
pertencem às primeiras gerações de mulheres de Cacheu que se casaram com comerciantes estrangeiros ou com seus descendentes envolvidos no comércio transatlântico.

Crispina Peres nasceu em c.1615, em Geba, onde seus pais eram comerciantes. Ela tinha um irmão, Antônio Peres Baltazar. Quando ela tinha 9 anos (c. 1624), a família se mudou para Cacheu (Mapa 1), por causa do aumento das atividades comerciais na referida vila. Lá, Crispina viveu sua adolescência e aprendeu a arte do comércio com sua mãe e outras comerciantes.

Algumas pesquisas supõem que, na referida região, mulheres chamadas arbitrariamente pela historiografia de Luso-Africans, Eurafricans, crioulas, mestiças etc. tinham mais possibilidade de ascensão social e participação nos negócios com estrangeiros europeus do que as que não eram mestiças. Brooks fez uma comparação entre mulheres Luso-Africans e africanas. Conforme sua interpretação, as primeiras eram preferidas pelos europeus porque acumulavam alguns critérios de distinção: eram católicas, tinham a pele mais clara, sabiam falar crioulo, tinham relações parentais com comerciantes africanos e lusoafricanos, conheciam melhor os gostos e necessidades dos europeus, vestiam-se e adornavam-se à moda europeia, possuíam casas com objetos europeus, possuíam embarcações feitas localmente para praticar o comércio inter-regional, tinham escravos domésticos, marinheiros e habilidosos artesãos que trabalhavam para elas. Nas palavras de Brooks (2003, p. 125): "Luso-African women generally possessed lighter pigmentation than African women, and some European men no doubt allowed color prejudice to outweight kinship and commercial advantages." De outro lado, as “africanas" seriam menos preferidas porque eram "pagãs", tinham a pele mais escura, não dominavam o português ou a língua crioula para atuar como intérpretes, possuíam contatos mais localizados, portanto, mais restritos, e nem tinham as mesmas habilidades que as "Luso-Africanas" para as parcerias comerciais.

Esta interpretação de Brooks, baseada na distinção entre o que significava ser "africana” e o que significava ser "Luso-Africana" é ideográfica e não deve ser tomada como padrão. A afirmação de Brooks é problemática porque demarca uma suposta superioridade das mulheres “Luso-Africanas" em relação às mulheres nascidas localmente. A base empírica é fundamental para questionar essas convenções binárias e suas implicações sociais naquele momento. Nas fontes que analisei, na região ao sul do Gâmbia, a mestiçagem não parece ter sido central para o sucesso das mulheres. Crispina Peres, foco deste texto, tinha uma ascendência estrangeira, contudo, várias mulheres da região que se casaram com europeus não possuíam qualquer ascendência europeia e nem se identificavam a partir de parâmetros binários ou europeus. Ao invés de mergulhar nesta polarização entre africanas x lusoafricanas, sugiro utilizar o termo da documentação "filha ou filho da Guiné", marco usado no período para pessoas da Guiné que tinham alguma ascendência europeia no século XVII.

Em Cacheu e povoados vizinhos várias mulheres comerciantes casaram-se com europeus, a despeito da ausência de ascendência europeia e pertencimento a sociedades "estratificadas". ${ }^{5}$ Tais

\footnotetext{
${ }^{5}$ Brooks (2003, p. 127) separa as sociedades oeste africanas em "acéfalas" (ao sul do Rio Gâmbia) e "estratificadas" (ao norte do Gâmbia e compreendendo os povos mandinga e jalofo). Diz ele que as mulheres do norte atuavam como "esposas", "intérpretes" e "parceiras comerciais".
} 
mulheres aproveitaram as oportunidades oferecidas pelo comércio atlântico e as relações com os homens europeus para negociar suas posições sociais e econômicas e, também, controlar seus negócios. Isabel Lopes, uma das mulheres que aparecem no processo de Crispina, pois era amiga desta, tinha uma casa própria em Cacheu. Lopes reclamou seu direito à herança do português Manoel Dias Cotrim, capitãomor de Cacheu, quando este faleceu em 1662. ${ }^{6}$ A mesma Isabel Lopes, em Cacheu, depois do falecimento de Cotrim, teve outro arranjo amoroso com um "castelhano" que fazia negócios naquela praça. ${ }^{7}$ Outra mulher natural de Cacheu, Bibiana Vaz, uma poderosa empreendedora comercial, era casada com um rico comerciante Ambrósio Gomes. A mão deste dito Ambrósio Gomes, Theodosia Gomes (ou May Gomes), nascida numa das ilhas dos Bijagós, morava em Cacheu, casou-se com um português e teve um filho. Por fim, Susana e Vitória eram igualmente africanas, tiveram filhos com o rico comerciante João Batista Peres. Quando este faleceu, deixou algumas heranças para elas e seus filhos. Este caso será explorado mais à frente.

Há muito mais exemplos de casamentos entre estrangeiros e seus descendentes com mulheres da região de Cacheu que não eram "luso-africanas". Para concluir este ponto, ofereço mais um exemplo contundente. La Courbe registrou que quando chegou em Guinala, onde havia várias "casas portuguesas", ele encontrou um homem inglês em sua própria embarcação, que lhe ofereceu comida. A bordo do barco, este inglês contou para La Courbe que era católico e "casado em 'Serrelione' com uma senhora negra do interior que deu a ele uma ilha onde ele estava cultivando. Seu barco poderia ser de 40 a 50 toneladas e foi batido em Serra Leoa com madeira do país" (LA COURBE, 1913, p. 228). Esta evidência mostra que o inglês se casou com uma "uma senhora negra" e, como resultado dos arranjos de casamento com esta senhora, teve acesso a terras para cultivar e utilizava-se de um navio construído por especialistas em navegação de Serra Leoa. Obviamente que tudo isso foi feito por trabalhadores arranjados e comandados por ela, e não por ele. Assim como a esposa do inglês, Crispina também era chamada de Senhora.

Os fatos mostram que as relações locais, as conexões inter-regionais e atlânticas destas mulheres bem como seus conhecimentos acerca dos grupos mercantis do interior e da costa eram mais importantes para elas e para seus negócios do que a superestimada "mestiçagem". O meu argumento acerca deste debate sobre as mulheres da Guiné considera que, independente de serem mestiças, a prosperidade, a propriedade e a mobilidade social daquelas mulheres não eram bem vistas nem pelos mercadores e autoridades europeias, nem pelas pessoas nascidas na região. O acúmulo de propriedades e a mobilidade criavam uma diferenciação social local, que era imputada ao uso de forças sobrenaturais. Esta situação de destaque lançava mulheres da elite a situações de insegurança e violência naquelas sociedades, como foi o caso de Crispina Peres.

\footnotetext{
${ }^{6}$ AHU - Guiné, cx. 2, doc. 29/[ant. 1663, Novembro, 24] Requerimento de Isabel Lopes e mais herdeiros do falecido capitãomor de Cacheu, Manuel Dias Cotrim, ao rei [D. Afonso VI] solicitando que o governador e capitão-general de Cabo Verde verificasse se o defunto devia alguma coisa à Fazenda Real e que acertadas as contas, devolvesse rapidamente os bens sequestrados. AHU-Guiné, cx. 2, doc. 29. AHU_CU_049, Cx. 2, D. 107, 24/11/1663.

7 ANTT, TSO, IL, Processo 2079 (1668).
} 


\section{A TRAJETÓRIA DE CRISPINA PERES EM CACHEU E SUA MOBILIDADE SOCIAL}

No início do século XVII, Cacheu era o principal porto ao sul do Gâmbia. Em 1604, a povoação recebeu a primeira missão dos Jesuítas enviada para Cabo Verde e Guiné. Em 1605, o povoado foi elevado à categoria de Vila de Nossa Senhora do Vencimento. A ocupação da Vila pelos comerciantes portugueses e seus descendentes foi iniciada porque se apresentava como local seguro para eles. Além disso, possuía posição estratégica para o comércio com o interior, por meio dos rios Gâmbia, Casamance, Cacheu, Farim, Corubal, Grande, Geba e Serra Leoa; bem como para o exterior, via Oceano Atlântico. O padre Baltazar Barreira, que chegou à Guiné na primeira leva da referida missão dos jesuítas, anotou em suas cartas missionárias sobre o intenso comércio que havia naquela praça, assim como os conflitos e ausências de missionários: "Cacheu, que é a povoação de mais portugueses, e mais grosso trato, que há nesta Guiné, e onde há mais desordens e maiores necessidades espirituais". ${ }^{8}$

Neste sentido, na primeira metade do século XVII, Cacheu havia se consolidado como um dos principais portos da Senegâmbia, de onde eram exportadas pessoas para o trabalho escravo nas Américas, especialmente Colômbia e Peru (BÜHNEN, 1993; HAWTHORNE, 2003; NEWSON, 2013; NEWSON; MINCHIN, 2007; ÁLVARES, 1616, DONELHA, 1979). Cacheu era um importante porto, por onde transitavam pessoas de diversas nações africanas e europeias, como Portugal, França, Holanda, Inglaterra, Espanha, Peru, Colômbia etc. No período abordado neste artigo, homens europeus se integraram a redes mercantis inter-regionais (BROOKS, 1993) de Banhuns, Biafadas, Papeis, Sapes, Mandingas etc. Em Cacheu, eram comercializados diversos tipos de produtos locais, como marfim, cera, panos, ouro, algália e pessoas escravizadas (MALACCO). Os produtos comprados dos viajantes estrangeiros eram os mais variados e atendiam aos gostos das populações que viviam ali e, também, de moradores nos outros portos ao redor. Europeus vendiam algodão cru, ferro, contas, vinho, aguardente etc. Essas são as informações das fontes escritas. As pesquisas arqueológicas poderão trazer evidências mais ricas das trocas que aconteciam em Cacheu a partir da cultura material regional. ${ }^{9}$

Cacheu estava dividida em dois bairros - a Villa Fria e a Villa Quente -, conforme descrições coetâneas. Na Villa Fria viviam mercadores e autoridades portuguesas e cabo-verdianas e ali estavam instaladas as poucas instituições portuguesas: uma igreja, a fortaleza, a casa do capitão-mor e outras, de outros poderosos comerciantes. No outro bairro, separado do anterior por uma paliçada, moravam os africanos, também mercadores e mercadoras associadas a redes mercantis locais, que desempenham funções essenciais para o comércio atlântico. Este bairro tinha duas denominações: Santo Antônio e Villa Quente. Francisco de Lemos Coelho, em 1669, descreveu de forma negativa esta outra parte da povoação:

\footnotetext{
${ }^{8}$ Carta do Padre Baltasar Barreira ao Provincial da Companhia de Jesus (20-2-1606) apud Brásio (1968, p. 98).

9 O Arqueólogo Português Rui Gomes Coelho está conduzindo o projeto "Memorial da escravatura e do tráfico negreiro de Cacheu", desde 2020.
} 
O dito Bairro da Vila Quente he habitado por grumetes forros, e de negros gentios pescadores, e hum cubil de ladroens muy prejudicial á dita povoação a qual mais della he em que vivem os brancos, ou os Deozes de Guiné, que assim lhe chama o gentio, e verdadeiramente se lhe pode chamar, por que he só parte Guiné hoje, que cada hum pode viver como quizer, sem haver quem lho contradiga (LEMOS COELHO, 1990, p. 171)

Para o autor do relato, um cabo-verdiano que vivia em Cacheu, a Villa Quente e, também, a Guiné pareciam espaços caóticos, em razão da mistura de vários elementos culturais. A nomenclatura das vilas como Fria e Quente não se referia ao clima, mas à intensidade das vivências sociais nestes espaços. Este retrato depreciativo feito por um morador de Cacheu, que era mestiço, mostra que Cacheu não era um lugar da harmonia dos encontros culturais, onde se formou uma comunidade "luso-africana". Lemos Coelho mostra que havia nítidas diferenças entre os diferentes segmentos sociais, bem como uma visão muito pejorativa em relação aos negros.

A Villa Quente era perto da igreja de Santo Antônio e do porto, onde se realizava todo o comércio daquela praça (Figura 3). Segundo Crispina Peres, sua instrução como católica foi realizada pelo pai, que a ensinou algumas orações. Como não havia igreja em Geba, ela foi batizada às pressas "por huma pessoa secular" quando era criança e encontrava-se muito doente, na casa de seus pais, para não morrer pagã. Assim, quando a família de Crispina Peres se mudou para Cacheu, "lhes poserão os S.tos Oleos." "10 Ela não foi crismada e não teve oportunidade de aprender a ler e escrever. Durante sua adolescência, Crispina Peres, assim como outras jovens de famílias de comerciantes de Cacheu, acompanhava o cotidiano dos negócios da família.

Em Cacheu, Crispina foi instruída sobre a vida religiosa local, que misturava elementos do catolicismo com a religião Yran (PEREIRA, 2020; FREITAS, 2016). Ela morava na Vila Quente, próxima à Igreja de Santo Antônio (Figura 3). Crispina Peres casou-se jovem, por volta de 1630-1635, com o capitão Francisco Nunes Dandrade ${ }^{11}$, comerciante de escravizados, com quem teve três filhos: Rodrigo Nunes, George Nunes e Cassila Nunes. Tudo indica que, em Cacheu, as mulheres livres tinham liberdade para escolher seus companheiros para relações de longa ou curta duração. Branca Rolva, Felipa Mendes, Isabel Lopes e Francisca Monteira foram acusadas pelo padre Gaspar Vogado de tratarem com "feitiseiros para efeito de que homens lhe quisessem bem e pera ser rica". ${ }^{12}$ As acusações contra mulheres de fazerem feitiços para conquistarem os homens e obterem prosperidade expõem que as mulheres podiam escolher seus parceiros em Cacheu, sem a interferência de autoridades locais.

Por via de regra, Crispina Peres também escolheu seus parceiros. Após o falecimento de Francisco Nunes Dandrade, Crispina Peres casou-se com um "filho da terra", Jorge Gonçalves Francês, em 1655, com quem teve apenas uma filha, Eleonor, que faleceu ainda bebê. Seu segundo marido sofria

\footnotetext{
${ }^{10}$ ANTT, TSO, IL, Processo 2079 (1668), fl. 135.

${ }^{11}$ Os primeiros registros de Francisco Nunes Dandrade [ou de Andrada] são referentes aos anos 1616-1617 e foram feitos pelo comerciante português Manuel Bautista Pérez, residente no Peru, que fez um contrato com Dandrade para que este fosse resgatar escravizados em Ziguinchor (NEWSON, 2007, p. 51-52).

12 ANTT, TSO, IL, Processo 2079 (1668), fl.13.
} 
de uma severa artrite, conhecida popularmente como gota. ${ }^{13}$ Esta inflamação que afeta as articulações do corpo, manteve Jorge Francês inoperante e acamado por longos períodos, logo, sem capacidade de exercer seus negócios. Diante dessa situação, Crispina tocou os negócios da família juntamente com seus escravizados/as, grumetes/as, marinheiros e a criadagem que vivia em sua casa.

Figura 3 - Prospecto da Vila de Cacheu, em 1678

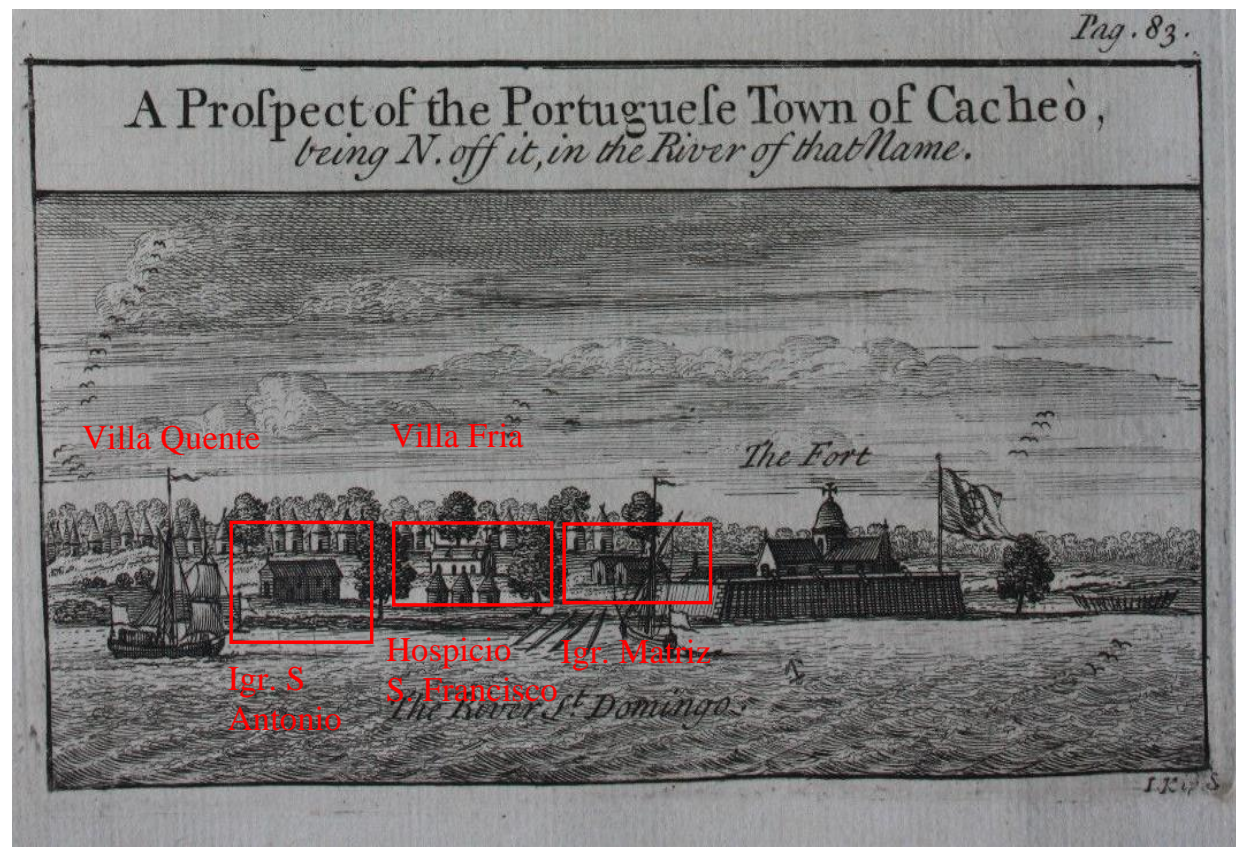

Fonte: Intervenção da autora sobre imagem de BARBOT, Jean. A prospect of the Portuguese Town of Cacheo. In: A Description of the coasts of north and south-Guinea [1678 e 1682], p. 83 (detalhe)

Os registros realizados pela Inquisição portuguesa entre 1655 e 1668 trazem muitas informações sobre o passado de Crispina Peres, mas não há detalhes sobre as propriedades que tinha quando se casou com o segundo marido. De todo modo, conforme as regras da terra, ela e os filhos herdaram propriedades do casamento com Francisco Nunes Dandrade. ${ }^{14}$ Dois exemplos de que as mulheres herdavam os bens dos maridos estrangeiros são os casos de Susana e Vitória. Elas tinham relacionamento com João Batista Peres, cristão-novo, comerciante e residente no Peru. Ele fazia trato de escravizados em Cacheu e região, onde passava longas temporadas e tinha as duas citadas mulheres como companheiras. No seu testamento, João Batista Peres reconheceu dois filhos e duas filhas que teve com Susana e Vitória, respectivamente. Para Susana e as meninas, deixou uma casa onde ela vivia, $200 \mathrm{~kg}$ de algodão e vinte varas de pano ruão. Pode-se presumir que Susana atuava no ramo de panos. Para Vitória e os meninos, ele arranjou uma forma de enviá-los para Portugal. O pai também declarou o primogênito

\footnotetext{
${ }^{13}$ Gota é uma doença provocada pelo acúmulo de depósitos de cristais de ácido úrico nas articulações devido a concentrações elevadas de ácido úrico no sangue. O acúmulo de cristais causa crises inflamatórias dolorosas nas articulações ou ao seu redor. 14 Algumas regras da terra para o casamento foram registradas por Almada (1594, p. 163): "Costumam os homens em todo Guiné darem o casamento, e as mulheres não trazerem nada. Quem quer casar dá ao pai da mulher, ou a seu tio, não tendo pai, peças de escravos e vacas e outras cousas que se têm por dinheiro entre eles. Segundo a qualidade das pessoas assim dão os dotes".
} 
de Vitória como livre. Além disso, João Batista Peres deixou 1.000 cruzados para serem divididos entre seus quatro filhos. ${ }^{15}$

Crispina Peres também herdou propriedades deixadas pela mãe e pelo pai. Contudo, mais importante do que as propriedades, Crispina Peres recebeu a extensa clientela deixada pelos pais e pelo marido defunto. Assim, ao se casar com Jorge Gonçalves Francês, "filho da terra", que já era comerciante de prestígio, Crispina juntou as propriedades dela às dele e, juntos, eles tornaram-se um poderoso casal de comerciantes nascidos em Cacheu com conexões atlânticas e inter-regionais. Quando foi denunciada à Inquisição de Portugal, em 1655, Crispina Peres e o segundo marido possuíam uma quantidade considerável de propriedades: uma casa tipo compound, que era conectada à "casa de Estalagem de estrangeiros", um navio fluvial, casas de aluguel e muitos homens e mulheres feitos cativos para serem exportados.

Diferentemente das mulheres livres, as escravizadas estavam sujeitas à violência daquela praça comercial, onde circulavam homens locais e estrangeiros que passavam longas ou curtas temporadas. Há vários registros das mulheres da região violentadas pelos residentes. No porto de Farim, por exemplo, o padre Antonio Vaz recusava-se a confessar as "negras forras" na Igreja. Desonestamente, ele mandava as jovens para a sua casa, onde abusava delas, como fez com a jovem Páscoa. ${ }^{16} \mathrm{O}$ padre também era acusado de ter "solicitado" (termo da inquisição para assédio sexual) Maria Roiz, que foi "molher" do Alferes Pero Nune. A abastada comerciante Crispina Peres também foi acusada de ter deixado Giria, "sua escrava", morrer amarrada "em grilhões", sem receber o batismo. ${ }^{17}$

\section{A DEMONIZAÇÃO DE CRISPINA PERES}

Crispina Peres foi denunciada à Inquisição Portuguesa por alguns moradores de Cacheu, que a acusavam de não praticar o catolicismo e de "usar das idolatrias e cerimônias gentílicas". Mas ela não estava sozinha. Mulheres e homens de Cacheu também estavam enredados em hábitos e costumes locais e foram denunciados aos agentes da inquisição instalados em Cacheu. $\mathrm{O}$ gênero das pessoas denunciadas em Cacheu era bem diferente do gênero dos acusadores. Das 21 denúncias, 15 foram contra mulheres e seis contra homens. Os homens estavam enquadrados em delitos de natureza sexual, heresia e superstição. As mulheres também foram denunciadas por crimes de ordem moral, superstição e "cerimônias gentílicas". Apenas uma jovem cometeu delito sexual, Catherina Monteiro, "creada de Manoel Salgado que foi ama do cônego Luís Rodrigues". Catherina Monteiro foi acusada de ter sido "manceba" do padre sodomita Antônio Vaz de Pontes e por ter permitido que a ela "consumisse por detrás". Ela também viveu juntamente com o cônego Luís Rodrigues, em Farim. Os inquisidores

\footnotetext{
15 Testamento de João Batista Peres, 12 janeiro 1617 (NEWSON, 2012, p. 12). Peres foi condenado à morte e executado pelo Santo Ofício de Lima, em 1617.

16 ANTT, TSO, IL, Processo 2079 (1668), fl. 10

${ }^{17}$ ANTT, TSO, IL, Processo 2079 (1668), fl. 55
} 
manipularam as informações para não escrever nos autos que Catherina Monteiro era escravizada e, principalmente, para culpá-la pelas relações sexuais que teve com os dois referidos padres. Somente três pessoas foram acusadas de cometer crime de "feitiçaria" ou "feitisseria": Júlia de Aguiar, seu filho e Crispina Peres. Algumas mulheres foram denunciadas pelos usos dos "costumes da terra", nomeadamente, porque procuraram os serviços dos jambacousses (autoridades religiosas locais) e participaram no "choro" (cerimônia fúnebre).

Das 28 pessoas ouvidas como testemunhas pelos agentes da inquisição em Cacheu, 26 eram homens. Dos homens, somente um era escravizado, Sebastião Barraça, criado de Crespina Peres. Os demais homens ocupavam cargos de escrivão, alferes, contramestre de navio, visitador-geral, capitães e grumetes. Apenas duas mulheres foram ouvidas, Maria Mendes e Natália Mendes. Apesar de 21 pessoas terem sido denunciadas, a única pessoa presa foi Crispina Peres. Como dito acima, havia várias acusações contra os dois padres que cometeram sodomia e viviam amancebados com rapazes e moças em Cacheu e em Farim. Aliás, a devassa foi iniciada para apurar os crimes dos padres; entretanto, Gaspar Vogado aproveitou-se da oportunidade para se vingar de Jorge Gonçalves e de Crispina Peres.

Qual era o ponto fulcral das denúncias contra Crispina Peres? Acusavam-na de dois delitos: o primeiro era crime de apostasia da fé porque ela não estaria praticando os mandamentos da Igreja, isto é, Crispina Peres não frequentava a igreja nos dias das principais festividades, não se confessava regularmente e comia carne na quaresma. Segundo as leis da Igreja Católica, deve-se comer apenas peixe na semana em que se celebra a morte de Cristo. O outro delito era de práticas gentílicas e feitiçarias: fazia culto às "chinas" e participava de práticas de cura realizadas pelas autoridades religiosas locais, os jambacousses e mulheres curandeiras. ${ }^{18}$ No cárcere da Inquisição de Lisboa, ela negou todas as acusações. Mas, sob tortura, confessou que recorria aos jambacousses e curandeiras sempre que precisava.

Na visão dos europeus, "chinas" eram objetos de adoração e superstição. Contudo, eles estavam equivocados. O que eles chamavam de "chinas" eram objetos no formato de forquilhas de madeira, colocados pelos jambacousses (sacerdotes) em lugares específicos para que eles e outras pessoas pudessem levar oferendas aos ancestrais e manter comunicação com o mundo sobrenatural, na esperança de receberem proteção de seus ancestrais. As oferendas eram feitas sobre as forquilhas e, também, em árvores, locais onde residem a força espiritual. As vasilhas de barro, conhecidas como testos, podiam ser colocadas junto às forquilhas e também em ambientes particulares. Os testos eram/são colocados com água, embaixo da cama para cuidar dos ancestrais da família.

O fato de parcela da população batizada de Cacheu considerar-se como "cristã" não impedia que as pessoas batizadas usassem práticas de cura locais e buscassem os jambacousses quando estavam doentes e tinham outros problemas ordinários. O que os denunciadores viram como "feitiçaria" não tinha nada a ver com a acepção europeia do termo. A população buscava tratamento espiritual para

18 O Regimento de 1640 (livro III, título XIV) discorre que os feiticeiros e os que têm pacto com o demônio seriam punidos e chamados de herege. Essas recomendações ficaram em vigência até 1774 (Cf. SIQUEIRA, 1996). 
atender aos seus anseios cotidianos e inseguranças de um mundo hierarquizado. Crispina Peres contou que, quando era uma criança de 12 anos, seu braço estava enfermo; então, seus pais chamaram Dom Batã Costa, um jambacousse de nação Papel, morador de Cacheu. Este jambacousse curou Crispina Peres por meio da aplicação no braço de emplastros feitos com ervas e o sangue de uma cabra que foi sacrificada para esta finalidade. ${ }^{19}$ Quando o marido de Crispina estava seriamente doente na cama, ela mandou chamar os jambacousses para curá-lo. ${ }^{20}$ Além de homens que tinham poderes especiais para lidar com o mundo invisível, como os jambacousses, havia também mulheres que conheciam práticas de cura.

Em outras situações de enfermidades, Crispina Peres recorreu a essas mulheres que tinham experiências com práticas de cura. Assim, ela revelou uma intensa rede de sociabilidade entre mulheres com diferentes habilidades e conexões com o interior. Quando Eleonor, filha recém-nascida de Crispina Peres, adoeceu de mau-olhado, ela recebeu ajuda de uma mulher Bijagó, Teodosia Gomes (mãe de Ambrósio Gomes, sogra de Bibiana Vaz), que foi buscar os jambacousses na terra dos Banhuns, em Guinguim e Buguendo. Ela também contou que quando adoeceu do pé foi curada por uma mulher, chamada Chicambena, filha de uma "huma gentia casta Sapi", a "qual a curou com as panelas que chamam chinas". Natália Mendes, uma mulher preta fiandeira e lavadeira, casada com Prique-Prique, confessou aos agentes locais da inquisição, sem receios e com bastante convicção, que também tinha tentado curar Jorge Gonçalves Francês.

Além destas, outras acusações feitas pela população local aumentaram a gravidade da denúncia contra Crispina Peres. Moradores de Cacheu queixaram Crispina Peres de ter adoecido o marido com ervas e feitiços para mantê-lo inoperante na cama e dominar os negócios da família. Acusaram-na de ter permitido aos jambacousses ministrarem remédios para a recém-nascida Eleonor, que veio a falecer. Este fato teria acontecido 10 anos antes, por volta de 1655, logo após ela casar com Jorge Gonçalves, mas os moradores desencavaram todos os fatos antigos naquele momento. Incriminaram-na de possuir uma "cobra Hirã", que "tomava figura humana", a qual foi supostamente encomendada aos jambacousses com a finalidade de lhe trazer bens e riquezas. Também disseram que ela herdou a tal cobra do pai, que supostamente usava um réptil para adquirir riquezas. A posse de uma cobra para obter riquezas tinha um peso forte nas crenças locais. A fortuna era atribuída às coisas danosas feitas contra outras pessoas para enriquecimento pessoal (HAWTHORNE, 2010, p. 217). Tão importante quanto esta crença, era a inveja da concorrência comercial. Inimigos e concorrentes comerciais utilizaram-se das interpretações das crenças locais para condenar a prosperidade de Crispina Peres e eliminá-la de Cacheu.

A denúncia sobre a cobra foi feita por dois agregados da casa: Sebastião Roiz Barraça e Vicente Fogaça. Segundo o padre Vaz, Sebastião Barraça não falava português e sua confissão foi traduzida por um intérprete. ${ }^{21} \mathrm{~A}$ declaração de Barraça tinha um peso enorme: ele era escravo de Crispina Peres e

\footnotetext{
${ }^{19}$ ANTT, TSO, IL, Processo 2079 (1668), fl. 137

20 ANTT, TSO, IL, Processo 2079 (1668), fls. 137-139.

21 Esta declaração do padre Vaz deve ser relativizada porque Sebastião Roiz Barraça escreveu uma carta em português, que foi anexada ao processo de Crispina Peres, na qual ele confessa que foi enganado pelos inimigos de sua senhora.
} 
morava na casa dela. Vicente Fogaça trabalhava como contramestre do navio de Crispina Peres e também morou na casa dela. Portanto, tecnicamente, ambos eram testemunhas oculares dos fatos dedurados.

Ao sentir-se vulnerável, e diante da possibilidade de prisão, Crispina Peres procurou alguém com conhecimentos sobre o direito português vigente para fazer a sua defesa. Em um documento, escrito em 29 de janeiro 1665, ela declarou que as acusações eram motivadas pelo fato de "ser mulher que negociava com todas as castas de negros gentios circunvizinhos [...] negros caboz, negros falupos, negros banhuns, negros calanga, negros das ilhetas, negros de baxere, negros de Pabuto, negros de Bamba e todos os mais grumetes de Farim". ${ }^{22}$ Nesta declaração, Crispina Peres dá uma mostra da abrangência dos seus negócios na região e do incômodo que isso causava em seus concorrentes. Com isto, ela também evidenciou o nó do problema: era uma mulher com negócios abrangentes, que alcançava povos que não comercializavam diretamente com os europeus. Ao manter vínculos com populações europeias e africanas, Crispina Peres gerou desconfiança nas autoridades portuguesas, cabo-verdianas e de naturais da Guiné e tornou-se vulnerável.

No contexto do século XVII, era impossível manter segredo de qualquer coisa em Cacheu ou em qualquer vila da Europa ou do Brasil. Os moradores de Cacheu estavam conectados por meio de uma estreita rede de relações, estimulada pelas fofocas e inimizades. Segundo a legislação Inquisitorial, as testemunhas do caso deviam manter segredo sobre o que foi tratado durante a inquirição feita pelo Comissário do Santo Ofício. Isto é, o denunciado não tinha o direito de conhecer o nome dos seus denunciantes, o lugar e o tempo onde o delito teria ocorrido. Tudo lhe era cuidadosamente ocultado (Regimento Inquisitorial, Livro II, Título IX, \1). Contudo, ao mandar escrever sua defesa, Crispina Peres sabia o nome de cada pessoa que a havia delatado ao comissário. Nas contraditas, ela expunha a trama arquitetada pelos inimigos do seu marido e cita o nome de 18 deles. ${ }^{23}$

\section{O uso da inquisição para punir inimigos e concorrentes comerciais}

Este vespeiro teve início em janeiro de 1656 com uma devassa aberta pelo Reverendo Doutor Gaspar Vogado, administrador geral das obras de Cacheu e visitador geral da Guiné. Segundo Crispina Peres, quando Jorge Gonçalves, seu marido, era capitão-mor de Cacheu, o referido administrador teria embarcado em um navio que ia para a ilha de Santiago. Contudo, o capitão-mor Jorge Gonçalves deu ordens para retirar Gaspar Vogado do navio porque o administrador não tinha concluído as obras da Coroa que tinha sido incumbido de fazer em Cacheu e também havia usurpado o dinheiro destinado para tais obras. Depois deste episódio, Gaspar Vogado sentiu-se humilhado e planejou sua vingança contra Gonçalves. Em conluio com os mais proeminentes comerciantes de Cacheu (Antônio da Fonseca Dornelles, Ambrósio Gomes e Vicente Roiz), Gaspar Vogado tramou uma devassa contra Jorge Gonçalves Francês. Assim, com o apoio institucional de um clérigo, que era representante da Coroa, este grupo passou a utilizar o tribunal da Inquisição como uma forma de ameaçar e de intimidar o casal: "e

22 ANTT, TSO, IL, Processo 2079 (1668), fl. 84. Grifo meu

23 ANTT, TSO, IL, Processo 2079 (1668), fl. 84. 
estando todos elles presentes remetia a devaça_a que elles avião jurado perante o p. ${ }^{e}$ frei Paulo comissário per duas vias_e andava ameaçando publicam. ${ }^{\text {te }}$ com a sancta inquisição que ella_e aseu marido ouvera faser tirar de guiné per ser muito soberbo". ${ }^{24}$

De 1661 a 1665, os inquisidores demandaram várias inquirições em Cacheu para que a denúncia pudesse ser mais caracterizada, pois os inquisidores não sabiam nada sobre o complexo religioso dos povos que viviam em Cacheu. A primeira inquirição começou em primeiro de janeiro de 1661 e foi realizada na casa do Cônego Antônio Fernandes. Dez meses depois, o Comissário do Santo Ofício, Paulo de Lordelo, voltou a Cacheu com seus assistentes, como ordenado pelos inquisidores de Lisboa, para fazer nova inquirição com o objetivo de compreender detalhadamente como as mulheres "faziam as chinas e como cometeram o crime". Não se sabe o motivo, mas Paulo de Lordelo mudou o local da inquirição - saiu da casa do cônego e foi para o Hospício da Piedade (Figura 3).

Em janeiro de 1664, os inquisidores de Lisboa enviaram outro interrogatório com sete questões para os agentes da inquisição em Cacheu. Estes agentes eram religiosos locais e estrangeiros que atuavam na região. Eles foram oficialmente nomeados para essa diligência específica. Desta vez, os inquisidores ordenaram que 17 pessoas fossem inquiridas em uma nova diligência. Os 'retificantes', aqueles que confirmavam sobre o conteúdo das falas das testemunhas, eram Antônio Fonseca Dornelas e seu sobrinho Francisco Dornelas de Vasconcelos, ambos inimigos de Crispina Peres. Sete meses depois, em agosto de 1664, a Mesa do Santo Ofício emitiu um despacho sobre o sumário de testemunhas, elaborado pelo Comissário franciscano Paulo de Lordelo, indicando a prisão de Crispina Peres.

Este processo, assim como outros documentos da Inquisição, apresentam os usos politicos do Tribunal (SILVA, 2002; MAIA, 2016; CHAGAS, 2021). Tudo indica que as acusações de feitiçaria imputadas a Crispina foram, também, uma forma dos comerciantes se vingarem de Jorge Gonçalves Francês sem colocarem as mãos nele. Uma prova disso é o fato de ele não ter se sido o alvo da denúncia. Como era casado com Crispina Peres e sabia de todas as atividades dela, ele deveria ter sido denunciado junto, como era usual na Inquisição. Contudo, considerando o contexto social e político de Cacheu, não era fácil formalizar uma incriminação contra Jorge Gonçalves Francês. Ele era homem, filho do português Álvaro Gonçalves Francês, um proeminente comerciante que foi capitão-mor de Cacheu nos anos 1630. Assim, como seu pai, Jorge Gonçalves também era um conhecido comerciante, bem relacionado com as autoridades locais e as portuguesas. Era considerado o homem "de mais credito e cabedal de que todos os senhores de Giné". ${ }^{25}$ Inclusive, em 5 de maio de 1664, o Conselho Ultramarino remeteu ao rei D. Afonso VI um requerimento do capitão Jorge Gonçalves Francês, no qual ele solicitava satisfação dos seus serviços de soldado, capitão de infantaria, capitão-de-mar-e-guerra e capitão-mor de Cacheu, provisoriamente, até à chegada do próximo capitão-mor. Ele pediu também o hábito de Cristo e uma tença (pensão). Importante notar que este requerimento foi enviado à Coroa no contexto das

${ }^{24}$ ANTT, TSO, IL, Processo 2079 (1668), fl. 84.

25 ANTT, TSO, IL, Processo 2079 (1668), fl. 117. 
denúncias contra ele e a esposa, o que pode indicar a tentativa de Jorge Gonçalves de obter algum foro de fidalguia que assegurasse alguma proteção para ele e para a esposa. Ele não conseguiu.

\section{A defesa de Crispina Peres}

Nas suas contraditas, Crispina Peres declarou os motivos pelos quais os moradores de Cacheu tinham feito a devassa contra ela e o seu marido. Segundo Crispina Peres, o capitão-mor Antônio da Fonseca Dornelas se tornou inimigo de Jorge Gonçalves, porque este não lhe dava fazendas e "regales", ou seja, gratificações pelas mercadorias vendidas no porto de Cacheu. Assim, Dornelas e seu sobrinho, maliciosamente, se ofereceram como testemunhas retificantes do Comissário do Santo Ofício, conforme indicamos acima. Ao assumir este encargo, Dornelas e o sobrinho tinham que informar ao Comissário sobre o grau de proximidade de cada testemunha com as pessoas denunciadas. Isto é, ambos tinham o poder em juízo de proceder contra o culpado. Assim, depois que a testemunha fazia os juramentos e se retirava do ambiente da inquirição, Dornelas e o sobrinho atestavam se a pessoa falava a verdade. Como era de se esperar, ambos "retificaram", isto é, desqualificaram e negaram os testemunhos de todas as pessoas que defenderam Crispina Peres e Jorge Gonçalves Francês.

Em relação ao depoimento de Ambrósio Gomes, Crispina Peres disse que quando Jorge Gonçalves Francês foi capitão-mor de Cacheu mandou prender Ambrósio Gomes. Por causa deste incidente, eles se tornaram inimigos capitais e tiveram muitas brigas, inclusive com armas: os dois "puxaram pellas espadas publicamente". ${ }^{26}$ Importante ressaltar que Jorge Gonçalves Francês foi nomeado no processo inquisitorial como "filho da terra" e Ambrósio Gomes foi designado como "filho de Guiné”, pois ambos nasceram em Cacheu. Ambrósio Gomes era filho de Teodósia Gomes, natural de uma das ilhas dos Bijagós, e um português. Este "filho de Guiné" tornou-se um dos mais ricos comerciantes daquela praça; inclusive tinha um navio para fazer resgate de escravos. Era casado com a famosa Bibiana Vaz, sobre a qual trataremos mais adiante. Este episódio entre dois comerciantes nascidos em Cacheu, com ascendência masculina portuguesa e ascendência feminina local, mostra que os conflitos englobavam também as relações animosas entre grupos mercantis locais e entre famílias de "filhos da terra".

No que se refere ao testemunho dos irmãos Vicente Roiz Duarte e João Roiz Duarte, Crispina Peres não disse explicitamente o motivo da inimizade do marido com os irmãos. Contudo, ela explicou sobre os negócios dos irmãos e enfatizou que ambos eram cristãos-novos, residentes no Peru; logo, pode-se entender que a inimizade entre os irmãos e o marido era causada pela concorrência comercial. Vicente Roiz Duarte e João Roiz Duarte eram cristãos-novos que fugiram do Santo Ofício de Lima para Cacheu. Eles faziam parte dos comerciantes conectados ao tráfico transatlântico de escravos.

No que concerne a Vicente Fogaça, outra pessoa da lista de inimigos que depôs contra o casal, Crispina Peres revelou que ele era marinheiro, levado para Cacheu pelos irmãos Vicente Roiz Duarte e

\footnotetext{
${ }^{26}$ ANTT, TSO, IL, Processo 2079 (1668), fl. 84.
} 
João Roiz Duarte. Fogaça morava há 23 anos em Cacheu e trabalhou por muitos anos como contramestre do navio de João Roiz Duarte. Depois de romper relações com este, foi trabalhar como contramestre do navio de Crispina Peres. Contudo, após um período de três anos trabalhando para sua nova senhora, as relações de trabalho e de confiança foram rompidas.

Sobre o depoimento de outros comerciantes daquele enclave, com menos poder que os citados acima, Crispina Peres também explicou o motivo pelo qual eles se tornaram inimigos do casal. Afirmou que Jorge Gonçalves Francês ajudou a alforriar dois escravos (Gaspar Roiz e sua irmã Esperanza Roiz) que pertenciam ao João Roiz da Costa. Por sua vez, Luiz de Moura, que era sobrinho de João Roiz da Costa, tomou as dores do tio e tornou-se inimigo do casal. Luiz de Moura, natural de Lisboa, morava em Cacheu há 21 anos. Crispina Peres ainda acrescentou um detalhe importante da rede de contatos locais que faziam parte do conluio: Luiz de Moura era, também, compadre de dois outros inimigos do casal, Ambrósio Gomes e Vicente Roiz Duarte.

Em referência a Antônio Mendes Fragoso e João Nunes Castanho, eles eram naturais de Cabo Verde, comerciantes, cunhados de Jorge Gonçalves. Ambos faziam navegação entre Cacheu e Santiago e se hospedavam na casa de Crispina Peres quando estavam em Cacheu. Jorge Gonçalves declarou, no documento de sua defesa enviado para a Inquisição de Lisboa, que ambos eram pobres; e haviam se mudado de Cabo Verde para Cacheu na expectativa de trabalhar em parceria com ele para enriquecer. Os dois cabo-verdianos romperam relação com o casal porque alegavam que Jorge Gonçalves "não lhes dava m. ${ }^{\text {to }}$ dinheiro" por causa de Crispina Peres. Fica explícito, aqui, que Crispina Peres gerenciava o pagamento dos atravessadores que levavam cativos de Cacheu para Cabo Verde.

Quanto a Pedro Paes (escrivão, natural de Cacheu) e sua tia Maria Mendes (natural de Santiago, preta forra, solteira, morava em Cacheu há 40 anos), eles se tornaram inimigos de Jorge Gonçalves Francês e Crispina Peres porque Maria Mendes foi expulsa da casa arrendada por Jorge Gonçalves Francês, onde vivia com Pedro Paes, por inadimplência. Esta casa era separada da residência de Crispina Peres por uma parede. Bastante doente, com 80 anos e com medo de morrer sem falar a verdade, Maria Mendes confessou ao padre que participou da cerimônia de cura da pequenina Eleonor; e afirmou que Crispina Peres usava "cordões mandingas". Na prisão, Crispina Peres assumiu que Maria Mendes fez várias coisas para ela: lhe arranjou os cordões mandingas para ter bens e riquezas, fez uma bolsa de pano e defumou o amuleto de guarda antes de colocar no pescoço de Leonor. Em sua confissão, o capitãomor Dornellas explicou que Maria Mendes era muito próxima de Crispina Peres e das mulheres da casa de Crispina Peres. Ou seja, tudo indica que Maria Mendes se vingou da amiga por causa do fim da locação da casa onde morava.

Com relação ao padre Antônio Vaz de Pontes, português, vigário de Cacheu, Crispina Peres sustentou que o motivo da denúncia feita pelo referido padre devia-se ao fato de que o vigário teve uma contenda pública contra Jorge Gonçalves Francês. Este xingou o padre com os seguintes palavrões: "puto e somítico per ter heça fama he bêbado de ser sodomita e viver amancebado com homens e mulheres". Jorge Gonçalves Francês e o padre Vaz de Pontes foram às vias de fato e quase houve um 
homicídio. Além das acusações de sodomia e de viver amancebado com homens e mulheres, o padre também era acusado de atuar como mercador de escravos em Cacheu.

No tocante ao capitão Francisco de Lemos Coelho, certamente, ele é a pessoa mais conhecida deste artigo, pois trata-se do autor da bem conhecida e já citada obra Descripșão da Costa de Guiné (16691684). Este comerciante e conhecedor da região viveu por volta de duas décadas em Cacheu. Um dia, Lemos Coelho lutou publicamente com espadas com Manuel Luis Francês, sobrinho de Jorge Gonçalves Francês. Lemos Coelho saiu vencido e ferido, mas Jorge protegeu o sobrinho. Este foi o motivo declarado por Crispina sobre a causa da inimizade entre Jorge Gonçalves Francês e Francisco Lemos Coelho.

No que tange aos irmãos Domingos de Areda e Matheus de Areda, Crispina Peres também se defendeu das denúncias deles. Ela disse que os irmãos foram motivados a fazer a denúncia porque roubaram mercadorias dela e, logo, foram expulsos da sua casa. Em 1646, Jorge Gonçalves Francês, "resgatou" do "alcaide" do porto de Sara, Casamance, quatro pessoas da mesma família: dois irmãos juntamente com a mãe e outro filho pequeno. Tudo indica que, com a morte do marido europeu, a mãe das crianças (sem nome) e os filhos foram sujeitados pelo "Rei de Cazamança". Após o resgate, Jorge Gonçalves os levou para a sua casa e os batizou. Quando Jorge Gonçalves Francês se casou com Crispina Peres, em 1655, toda a família Areda foi morar na "casa de Crispina". Aqui, temos um detalhe importante. Crispina Peres era proprietária da casa onde morava com Jorge. Os irmãos Areda eram grumetes de Jorge Gonçalves Francês e Crispina Peres. Quando adultos, os irmãos Areda foram expulsos da casa do casal sob a alegação de terem roubado cativos e outras fazendas durante uma viagem a serviço do casal. Uma vez expulsos, os irmãos associaram-se aos inimigos do casal: um foi trabalhar com Ambrósio Gomes; e o outro com Jorge Castanho (cunhado e inimigo de Jorge Gonçalves Francês) e casou-se com a filha do primo carnal de Ambrósio Gomes.

Por fim, Crispina Peres defendeu-se da acusação feita por Sebastião Roiz Barraça, seu escravizado. Ela alegou que Ambrósio Gomes, Vicente Roiz e Gaspar Vogado ofereceram bebida alcoólica a Sebastião para mantê-lo bêbado e sob a promessa de alforriá-lo, fizeram-no testemunhar contra ela. Sebastião Roiz Barraça fez uma das revelações mais graves contra Crispina Peres: relatou que ela tinha uma "cobra Hirã" para lhe trazer riquezas. Contudo, após a prisão de Crispina Peres, Sebastião ou se arrependeu do falso testemunho ou foi forçado a reconhecer que mentiu aos agentes da Inquisição em Cacheu. Como era letrado, Barraça escreveu uma carta na qual contou que foi torturado pelos comerciantes supracitados para mentir durante o testemunho.

Conforme mostramos, em sua defesa, Crispina Peres revelou as intrigas contra o marido que se estendiam para ela, bem como abriu as portas do universo das relações entre as camadas sociais africana, portuguesa e de "filhos da terra", em Cacheu, no início da segunda metade do século XVII. Em virtude de sua posição de liderança na região, padres, comerciantes, administradores, escrivães, grumetes, forras, forros, mulheres e livres e escravizados levantaram várias acusações contra Crispina Peres. Assim, a 
análise dos depoimentos do processo inquisitorial contra Crispina Peres, transcorrido em Cacheu, possibilitam confrontação de diferentes vozes sociais e permitem recuperar os micropoderes locais.

\section{A repercussão da prisão}

As repercussões da diligência e da prisão de Crispina Peres mostraram o prestígio que ela tinha. Dois anos depois do início das investigações, em janeiro de 1663, "gentios da Matta"27 entraram no quarto de Paulo de Lordelo, o comissário do Santo Ofício, e levaram vários papeis com os registros das inquirições, além de papeis novos, deixando, assim, o comissário sem papel para anotar os relatos das demais testemunhas. O comissário escreveu uma longa carta aos inquisidores, com letras pequeníssimas, aproveitando todos os espaços da única folha de papel que lhe restava, para contar sobre o furto dos papeis; informou que estava muito doente, sangrando e pedia mais folhas. Sem provas, Lordelo conjecturou que talvez Jorge Gonçalves Francês tivesse mandado seus homens roubarem os papeis que estavam sob o seu poder. ${ }^{28}$

Em janeiro de 1665, na noite da prisão de Crispina Peres, 12 mil homens armados, de nação Papel, ameaçaram invadir e incendiar a vila de Cacheu. Jorge Gonçalves Francês não pôde usar seus prestígios para protegê-la. Contudo, ele escreveu aos inquisidores uma petição, pedindo a soltura da esposa, e advertiu que, por causa dela, os povos Papeis podiam incendiar Cacheu. Jorge não estava exagerando sobre as extensas redes de contato de Crispina Peres junto aos povos da região.

Outra evidência do prestígio de Crispina Peres está na carta que o vigário Gaspar Vogado, o padre Antônio Vaz da Ponte e seus adjuntos escreveram aos inquisidores para informar sobre a revolta popular que ocorreu depois da prisão. Este religiosos relataram que Crispina Peres era "muito nomeada e conhecida em toda Guiné, por Sertão e respeitada pella mais principal e poderosa de todas". ${ }^{29}$ Traduzindo claramente este texto do português antigo para o contemporâneo: Crispina Peres era a principal mulher de toda a Guiné e a mais poderosa. Assim, depois da prisão dela, os referidos religiosos tiveram que andar "com as armas nas mãos", vigiando todos os portos, receando que "os negros gentios nos ataquem a povoação porque conhecem o [pouco] poder e força que temos". ${ }^{30} \mathrm{Ou}$ seja, a prisão de Crispina Peres quebrou o pacto entre os donos da terra e a comunidade mercantil de Cacheu.

O equilíbrio das relações na Guiné se dava por meio da compra de produtos de comerciantes e de donos da terra, os quais recebiam em troca produtos de seus interesses, que vinham do exterior. A comunidade mercantil situada em Cacheu era composta de mulheres comerciantes, tangomãs, tangomãos e grumetes, todos nascidos na região, e também de europeus. Todo mundo se envolvia com o comércio de seres humanos, inclusive as autoridades religiosas e administrativas, que eram, teoricamente, proibidas de se envolverem em negócios privados. Os comerciantes estrangeiros compravam produtos diretamente de todos estes comerciantes instalados em portos, como Cacheu.

\footnotetext{
27 Mata é uma tabanca que fica próxima à Oeste de Cacheu.

28 ANTT, TSO, IL, Processo 2079 (1668), fl. 40.

29 ANTT, TSO, IL, Processo 2079 (1668), fl. 70.

30 ANTT, TSO, IL, Processo 2079 (1668), fl. 70.
} 
Contudo, os contatos com o interior eram feitos, principalmente, por pessoas nascidas na região. Conforme vimos, no caso dos irmãos Areda, eles recebiam as mercadorias de Crispina Peres e de Jorge Gonçalves Francês para ir ao interior e costa para comprarem pessoas escravizadas. Na obra já citada de Linda Newson (2007), ela mostra como os comerciantes do Peru distribuíam mercadorias para as viagens de resgate de escravos nos rios da Guiné. Assim, a prisão de Crispina afetava várias pessoas que trabalhavam para ela, como navegadores e experientes comerciantes, que conheciam os pontos de comércio onde poderiam fazer bons negócios. Sua prisão quebrava a articulação entre o interior e os portos transatlânticos, como Cacheu. Crispina era uma mulher que exercia uma liderança interiorana que não pode ser ignorada. Sua declaração mostra seu pertencimento às redes locais. A declaração de seu marido evidencia que prevalecia a jurisdição local/interior em Cacheu.

Outro exemplo da repercussão da prisão de Crispina Peres foi apresentado pelo Frei Luís de Chaves. De Cabo Verde, este capuchinho enviou uma carta aos inquisidores em Lisboa, informando das dificuldades em prender Crispina Peres e das ameaças que ele e outras autoridades passaram a sofrer em Cacheu:

nesta sua carta me encarregaraõ, não so com perigo da minha vida, mas de huã povoação inteira; [...] e assim o teve este negocio, cuja difficuldade era tao grande, que fora mais fácil prender-se o Duque de Cadaval em hua terra sua, q esta mulher em sua casa, e naõ pareça a vs ss ${ }^{\text {as }}$ encarecimento. ${ }^{31}$

Duque de Cadaval era um título nobiliárquico que pertencia naquele momento a $\mathrm{D}$. Nuno Alvares Pereira de Melo (1638-1727), português residente em Lisboa que ficou conhecido pelo papel político e diplomático desempenhado na Restauração da Coroa portuguesa e no seu Conselho de Estado. Ao comparar Crispina Peres com o referido Duque, o frei evidenciou a dimensão do poder de Crispina Peres em Cacheu e região. Assim, vários esforços foram feitos para libertá-la. Além das ameaças da população contra a vida dos portugueses, Jorge Gonçalves Francês conseguiu vários documentos para comprovar a inocência dela: petições, certificações de padres confirmando que ela tinha se confessado e retificações de pessoas que mentiram diante do Comissário do Santo Ofício em Cacheu, inclusive a já mencionada carta de Sebastião Barraça.

Mesmo com todos estes esforços de Jorge Gonçalves, Crispina Peres permaneceu três longos anos no cárcere da Inquisição de Lisboa, de 1665 até 1668. Lá, passou por todas as agruras: foi torturada várias vezes e ficou seriamente doente durante todo o ano de 1666. Após várias inquirições e confissões, em março de 1668 foi declarada culpada. Crispina Peres foi sentenciada pelos crimes de "uso de feiticeiros e das curas deles", "uso de ritos da gentilidade", uso de "cordões dos mandingas" e por ter encomendado uma bolsa com ervas para colocar no pescoço da filha que estava doente e morreu. Sua sentença foi lida no auto-de-fé, no Largo do Rocio, no Centro de Lisboa, onde ela caminhou em procissão usando sambenito, com uma vela acesa na mão, e ouviu suas penitências. Por fim, foi obrigada a pagar as despesas do processo no Tribunal, desde sua prisão, em 1665.

31 ANTT, TSO, IL, Processo 2079 (1668), fl. 45. 
Após cumprir parte da penitência, partiu no primeiro navio de Lisboa para Cacheu. Três meses depois, chegou em seu lar, onde encontrou seu marido Jorge Gonçalves ainda mais doente. Pouco tempo após seu retorno, em 1668, Crispina Peres ficou viúva pela segunda vez. A última informação que temos dela é um certificado do padre Custódio Ribeiro, emitido em 1669. Ele atestava que Crispina havia cumprido as penitências recomendadas pelos inquisidores: ela se confessou, comungou e participou nas principais festas religiosas de Cacheu. Ou seja, ela havia retomado o seu cotidiano em Cacheu e parece que estava sendo assistida acerca do cumprimento das regras da Igreja Católica.

Duas décadas depois deste fatídico episódio contra a família de Crispina Peres, Cacheu seria palco de outra revolta provocada por outra mulher, Bibiana Vaz, chamada pelas fontes de "a viúva" (RODNEY, 1970, chapter 8; HAVIK, 2002; BROOKS, 2003, p.146-150). Bibiana Vaz de França, mais conhecida como Na [do Kriolo, senhora], teve importante participação nas redes de comércio e também no processo de interação com os estrangeiros. Ela era Papel, de tradição matrilinear, nascida em Cacheu no início do século XVII. Era casada com Ambrósio Gomes, um dos principais negociantes da região, que se tornou inimigo de Crispina Peres. Juntamente com o seu marido, Bibiana dominava redes interregionais de comércio e comercializava diretamente com estrangeiros. Assim como Crispina Peres, Bibiana Vaz pertencia às famílias envolvidas no comércio nos rios da região e na costa. Estas mulheres, juntamente com seus maridos, nascidos em Cacheu, faziam parte da camada mercantil daquela praça.

Assim como Crispina Peres, Bibiana Vaz tornou-se conhecida por causa das disputas com as autoridades locais, representantes dos interesses portugueses. A criação da Companhia de Cacheu (1676) ameaçava o controle dos comerciantes "filhos da terra", pois a Companhia era parte das tentativas da Coroa portuguesa de proibir os moradores de Cacheu de negociar com os estrangeiros e de monopolizar o comércio. Após a morte do marido (1679), Bibiana Vaz passou a resistir ao projeto de monopólio português. Indignada, Bibiana Vaz e seu primo prenderam o capitão-mor de Cacheu, José Gonçalves de Oliveira, empossado em 1682, e colocaram algemas nele diante da comunidade. Em 1684, Bibiana declarou que fazia aquilo como uma punição pelo abuso de poder do referido capitão-mor. Durante 14 meses, ela manteve José Gonçalves de Oliveira preso em sua feitoria em Farim, a cerca de $200 \mathrm{~km}$ de Cacheu (RODNEY, 1970, chapter 8). Consequentemente, a Coroa portuguesa mandou fazer uma sindicância entre os moradores, os quais indicaram o protagonismo de Bibiana Vaz na revolta. Ela foi presa e mandada para Cabo Verde em 1687, onde ficou hospedada na casa de um "chefe linhageiro Banhun" (HAVIK, 2002, p. 95). O desfecho deste caso mostra o poder da família Vaz. Depois de alguns meses em Cabo Verde, hospedada na casa de um nobre, Bibiana Vaz foi libertada e enviada para Cacheu. Ela foi perdoada pela Coroa juntamente com o seu irmão e o seu primo, que a apoiaram diretamente.

Os exemplos citados acima apontam que Crispina Peres e Bibiana Vaz ganharam proeminência política e econômica a partir de seus negócios e com a viuvez. Crispina Peres casou-se pela segunda vez, mas diante da doença que levava à inoperância do marido, consequentemente, à ausência dele, Crispina Peres dominava os negócios da família e isto incomodava os concorrentes comerciais. Bibiana Vaz, por 
sua vez, já idosa, não se casou novamente, mas tomou o controle dos negócios e enfrentou as autoridades portuguesas em Cacheu.

Importante notar que ambas as viúvas se tornaram conhecidas por causa dos registros produzidos sobre elas, que são de natureza jurídica. O mesmo aconteceu com Esperança (ou Hope Heath), natural de Cacheu, que se tornou uma poderosa comerciante em St. James Port, no rio Gâmbia. Conhecemos a história de Esperança por causa das disputas pela herança dos seus falecidos maridos (KRIGER, 2019). A natureza dos registros - litígios e devassas civis e eclesiásticas - mostram que estes foram feitos porque aquelas mulheres se tornaram obstáculo para a sociedade local ou estrangeira. $\mathrm{O}$ problema era o protagonismo assumido por aquelas mulheres viúvas nos circuitos mercantis dos rios da Guiné e transatlânticos e na liderança política na região. O intervalo entre as devassas de Crispina Peres e Bibiana Vaz foi muito curto e tudo leva a crer que a inquirição contra Bibiana Vaz tinha o mesmo objetivo da investigação contra Crispina Peres: eliminar sua família da praça de Cacheu.

A análise de ambos os casos precisa levar em consideração os poderes locais, incluindo pessoas nascidas localmente e europeus. Crispina foi alvo de intrigas das elites mercantis, que queriam se vingar do marido. A inquisição foi usada para concretizar o plano de retaliação contra Jorge Gonçalves. Na impossibilidade de prendê-lo, direcionaram as denúncias para ela. O fato de ser uma mulher com amplas conexões locais e de ter se tornado uma liderança comercial, não lhe garantiu proteção quando a comunidade mercantil, repito, incluindo homens nascidos em Cacheu e em Cabo Verde, autoridades civis e religiosas, resolveram se reunir para bani-la daquela sociedade e confiscar seus bens.

De todo modo, não devemos perder de vista que seu retorno para Cacheu dos cárceres da Inquisição de Lisboa foi uma vitória, uma vez que centenas de pessoas morreram nos cárceres da Inquisição. Eu atribuo esse triunfo aos povos Papeis e da Matta, que atormentavam as autoridades que viviam em Cacheu. Sem o retorno de Crispina Peres para a sua casa, não haveria paz naquele porto. No final do ano do primeiro ano da prisão de Crispina, o padre de Cacheu enviou uma carta aos inquisidores, informando que, desde a prisão de Crispina Peres, havia revoltas, pois se "motinavam os negros gentios". Além disso, escravizados fugiram das casas dos comerciantes, e também da casa dos padres, para a floresta. O clima era de tensão e insegurança. Em suas negociações, o marido de Crispina comprometiase a falar com as pessoas que fugiram para retornarem aos seus compradores e também prometia pagar todas as despesas do Santo Ofício, caso a esposa fosse libertada.

\section{CONCLUSÃO}

Ao analisar aspectos da dinâmica social de Cacheu, através de um exame atento de vidas individuais ou eventos locais representativos envolvendo pessoas específicas, foi possível acessar biografias de mulheres guineenses e fazer uma história de Cacheu. Tradicionalmente, a historiografia enquadrou Cacheu como um espaço "crioulo", em virtude das "mestiçagens", mas, a história social mostra que Cacheu era uma comunidade onde mulheres que ali viviam tinham forte atuação na 
sociedade, independente de suas ascendências europeias, e que havia muito preconceito contra os chamados "negros". As mulheres de Cacheu não desempenhavam papel formal na administração, mas interferiam diretamente nos negócios, que era o ponto central da presença de funcionários da coroa naquela região. Assim, buscamos destacar o desempenho de algumas mulheres e seus poderes junto à comunidade local, pois, de uma perspectiva interna, é evidente que elas não eram meras assistentes dos homens. Este texto concentrou-se na micro-história de Crispina Peres para mostrar que a demonização de mulheres nas praças negras era uma estratégia para bani-las da sociedade. Esta foi a mesma estratégia para prender Bibiana Vaz Gomes, outra poderosa comerciante de Cacheu. Lá, a viuvez das mulheres negras livres dava-lhes mais liberdade para tocar os negócios e fortalecer suas casas comerciais, sem obrigações com regimes patriarcais e/ou patrilineares. Ao mesmo tempo, a viuvez fazia delas sujeitas que incomodavam a elite local.

\section{REFERÊNCIAS}

ALMADA, A. A. de. Tratado Breve dos rios da Guiné do Cabo Verde dês do Rio de Sanagá até os baixos de Santa Ana de todas as nações de negros que há na dita costa e de seus costumes, armas, trajos, juramentos, guerras. Feito pelo capitão André Álvares d'Almada natural da Ilha de Santiago de Cabo Verde prático e versado nas ditas partes. Ano 1594. In. BRÁSIO, Antonio (org.) Monumenta Missionaria Africana, África Ocidental. Coligida e anotada pelo Padre António Brásio. Série II, v. III (1570-1600). Lisboa: Agência Geral do Ultramar, 1964.

ÁLVARES, M. Etiópia Menor. Manuscrito da Sociedade de Geografia de Lisboa, 1616.

BARRY, B. Senegambia and the Atlantic Slave Trade. Cambridge: University Press, 2002.

BIVAR, M. P. A de. Kaabu, a história de um império do início ao fim. Tese (Doutorado em História) Universidade Estadual de Campinas, Campinas, 2018.

BRÁSIO, Antonio (org.) Monumenta Missionaria Africana, Africa Ocidental. Coligida e anotada pelo Padre António Brásio. Série II, v. IV (1600-1622). Lisboa: Agência Geral do Ultramar, 1968.

BRÁSIO, A. Monumenta Missionária Africana., v. 5, Lisboa: Agencia Geral do Ultramar, 1979.

BROOKS, G. Cacheu: A Papel and Luso-African Entrepôt at the Nexus of the Biafada-Sapi and Banyun-Bak Trade Networks. In: LOPES, C (org.). Mansas, escravos, grumetes e gentio: Cacheu na encruzilhada de civilizações. Bissau, Guiné-Bissau: Instituto Nacional de Estudos e Pesquisa, 1993. p. 173-198.

BROOKS, G. Eurafricans in Western Africa. Commerce, Social Status, Gender, and Religious Observance from the Sixteenth to the Eighteenth Century. Athens: Ohio University; Oxford: James Currey, 2003.

BROOKS, G. The Signares of Saint-Louis and Gorée: Women Enterpreneurs in Eighteenth-Century Senegal. In: HAFKIN, N. J.; BAY, E (org.). Women in Africa. Studies in social and Economic Change. Stanford: Stanford University Press, 1976. p. 19-44.

BÜHNEN, S. Ethnic Origins of Peruvian Slaves (1548-1650): Figures for Upper Guinea. Paideuma, v. 39, p. 57-110, 1993. 
CANDIDO, M. As comerciantes de Benguela na virada do século XVIII: o caso de dona Aguida Gonçalves. In: CANDIDO, M. et al (coord.). Laços Atlânticos: África e africanos durante a era do comércio transatlântico de escravos. Luanda: Museu Nacional da Escravatura, 2017. p. 231-258.

CANDIDO, M. P.; JONES, A. Introduction. In: CANDIDO, M. P.; JONES, A (ed.). African women in the Atlantic world: property, vulnerability \& mobility, 1660-1880. New edition ed; Boydell \& Brewer, 2019. p. 1-19.

CARREIRA, Antonio. A Etnonimia dos povos de entre o Gâmbia e o Estuário do Geba. Boletim Cultural da Guiné Portuguesa, v. XIX, 75, p. 233-275, 1964.

CHAGAS, F. G. Catharina Juliana nas Garras da Inquisição Portuguesa: uma micro-história da comunidade Afro-Atlântica do Reino de Angola (1710-1763). Dissertação (Mestrado em História Social) Universidade Federal de Minas Gerais, Belo Horizonte, 2021.

DIAS, E. C.; HORTA, J. da S. La Sénégambie: un concept historique et socioculturel et un object d'étude réevalués, Mande Studies, n. 9, p. 9-20, 2007.

DONELHA, A. Memorial de André Donelha a Francisco Vanconcelos da Cunha. [1625]. In: BRÁSIO, A. Monumenta Missionária Africana. Série II, v. 5, Lisboa: Agencia Geral do Ultramar, 1979. p. 90-146.

EVERTS, N. Parrying Palavers. Coastal Akan Women \& the Search for Security in the Eighteenth Century. In: CANDIDO, M. P.; JONES, A (ed.). African women in the Atlantic world: property, vulnerability \& mobility, 1660-1880. New edition ed; Boydell \& Brewer, 2019. p. 109-130.

FONSECA, M. B. Nzinga Mbandi e as guerras de resistência em Angola. Século XVII. Belo Horizonte: Mazza, 2015.

FREITAS, J. O. A religião dos barbacins, casangas, banhuns e papeis nos relatos de viagem na guiné (1560-1625). Dissertação (Mestrado em História) - Universidade Federal de Minas Gerais, Belo Horizonte, 2016.

FURTADO, J. F. Chica da Silva e o contratador dos diamantes: o outro lado do mito. São Paulo, Companhia das Letras, 2003.

HAVIK, P. A dinâmica das relações de gênero e parentesco num contexto comercial: um balanço comparativo da produção histórica sobre a região da Guiné-Bissau séculos XVII e XIX. Afro-Asia, n. 27, p. $79-120,2002$.

HAVIK, P. Comerciantes e Concubinas: sócios estratégicos no comércio Atlântico na Costa da Guiné. Rio de Janeiro. In: MOURÃO, F. A. (org.). A Dimensão Atlântica de África (Actas da II Reunião Internacional de História de África). São Paulo, CEA-USP; SDG-Marinha; CAPES, 1997. p. 161-179

HAVIK, P. Gendering the Black Atlantic: Women's Agency in Coastal Trade Settlements in the Guinea Bissau Region. In: CATTERALL, D; CAMPBELL, J. (org.). Women in Port. Gendering Communities, Economies, and Social Networks in Atlantic Port Cities, 1500-1800. Leiden: Brill, 2012. p. 315-356. (The Atlantic World, 25).

HAVIK, P. Silences and Soundbytes. The Gendered Dynamics of Trade and Brokerage in the Colonial Guinea-Bissau Region. Muenster: New Brunswick; Lit Verlag:Transaction Publishers, 2004.

HAWTHORNE, W. From Africa to Brazil. Culture, Identity and an Atlantic Slave Trade, 1600-1830. New York: Cambridge University Press, 2010. 
HAWTHORNE, W. Planting Rice and Harvesting Slaves. Transformations along the Guinea-Bissau coast, 1400-1900. Portsmouth, NH: Heinemann, 2003.

JONES, H. Women, Family \& Daily Life in Senegal's Nineteenth-Century Atlantic Towns In: CANDIDO, M. P.; JONES, A. African women in the Atlantic world: property, vulnerability \& mobility, 1660-1880. New edition ed; Boydell \& Brewer, 2019. p. 233-224.

KRIGER, C. E. From Child Slave to Madam Esperance: One Woman's Career in the Anglo-African World c. 1675-1707. In: CANDIDO, M. P.; JONES, A. African women in the Atlantic world: property, vulnerability \& mobility, 1660-1880. New Edition ed; Boydell \& Brewer, 2019. p.171-190.

LA COURBE, M. Le premier voyage du sieur de La Courbe Fait à la Coste d'Afrique en 1685. Paris: Société d'Histoire des Colonies Françaises, 1913.

LEMOS COELHO, F. de. Descripção da Costa de Guiné desde o cabo Verde athe a Serra Lioa com todas as ilhas e rios a que os brancos assistentes nella navegão (1669), Cód.307 da BNP. In: PERES, D. (ed.) Duas descrições seiscentistas da Guiné de Francisco de Lemos Coelho. Lisboa: Academia Portuguesa da História, 1990.

LEPORE, J. Historians Who Love Too Much: Reflections on Microhistory and Biography. The Journal of American History, v. 88, n. 1, p. 129-144, 2001.

LINDSAY, L. A. Biography in African History. History in Africa, v. 44, p. 11-26, 2017.

MAIA, M. Uma africana entre dois mundos. IN: BAETA, A.; Piló, H. (org.). Arêdes: recuperação ambiental e valorização de um sítio histórico-arqueológico. Belo Horizonte: Orange Editorial, 2016. p. 198-217.

MALACCO, F. O. O comércio atlântico em Cacheu: complementaridade mercantil e agência local, 1580-1700 (Capítulo de livro no prelo).

MARCUSSI, A. A. Cativeiro e cura: experiências religiosas da escravidão atlântica nos calundus de Luzia Pinta, séculos XVII-XVIII. Tese (Doutorado em História Social) - Universidade de São Paulo, São Paulo, 2015.

MOTT, L. O Calundu-Angola de Luzia Pinta: Sabará, 1739. Revista do LAC, Universidade Federal de Ouro Preto, p. 73-82, 1994.

MOTT, L. Rosa Egipciaca: uma santa africana no Brasil. Rio de Janeiro: Bertrand Brasil, 1993.

NEWSON, L. A. Africans and Luso-Africans in the Portuguese Slave Trade on The Upper Guinea Coast in the Early Seventeenth Century. The Journal of African History, v. 53, n. 1, p. 1-24, 2012.

NEWSON, L. A. Bartering for Slaves on the Upper Guinea Coast in the Early Seventeenth Century. In: GREEN, T. (org.). Brokers of Change: Atlantic Commerce and Cultures in Pre-Colonial Western Africa. London: British Academy; OUP, 2013. p. 257-282

NEWSON, L. A.; MINCHIN, Susie. From Capture to Sale: The Portuguese Slave Trade to Spanish South America in the Early Seventeenth Century. Leiden and Boston: Brill, 2007.

OLIVEIRA, V. dos S. Donas, pretas livres e escravas em Luanda (Séc. XIX). Estudos Ibero-Americanos, v. 44, n. 3, p. 447-456, 2018. 
OLIVEIRA, V. dos S. Spouses and Commercial Partners: Immigrant Men and Locally Born Women in Luanda 1831-1859. In: CANDIDO, M. P.; JONES, A. African women in the Atlantic world: property, vulnerability \& mobility, 1660-1880. New Edition ed; Boydell \& Brewer, 2019. p. 217-232.

PARES, L. N.; CASTILLO, L. E. Marcelina da Silva e seu mundo: novos dados para uma historiografia do candomblé ketu. Afro-Ásia, v. 36, p. 111-152, 2007.

PEREIRA, C. A. Se alguém morreu, alguém matou: Religião Yran na Senegâmbia entre 1446-1594. Dissertação (Mestrado em História) - Universidade Federal de Minas Gerais, Belo Horizonte, 2020.

RANGEL, F. B. O Império Português e o soldado feiticeiro: traduções religiosas na Angola setecentista. Trabalho de Conclusão de Curso (Graduação em História) - Universidade do Estado da Bahia, Itaberaba, 2012.

REGINALDO, L. André do Couto Godinho: homem preto, formado em Coimbra, missionário no congo em fins do século XVIII. Revista de História, v. 1, p. 141-174, 2015.

REIS, J. J. Domingos Pereira Sodré: um sacerdote africano na Bahia oitocentista. Afro-Asia, Salvador, v. 34, p. 237-313, 2006.

REIS, J. J. From Slave to Wealthy African Freedman: The Story of Manoel Joaquim Ricardo. In: LINDSAY, L. A.; SWEET, J. W. (org.). Black Atlantic Biography. Filadélfia: University of Pennsylvania Press, v. 1, 2014. p. 131-145

REIS, J. J. GOMES, F. S.; CARVALHO, M. J. O alufá Rufino: tráfico, escravidão e liberdade no Atlântico negro (1822-1853). São Paulo: Companhia das Letras, 2010.

RODNEY, W. A History of the Upper Guinea Coast, 1545-1800. New York: Oxford University Press, 1970.

SCHERER, J.; WEIMER, R. de A. No refluxo dos retornados: Custódio Joaquim de Almeida, o príncipe africano de Porto Alegre. Porto Alegre: Secretaria de Planejamento, Governança e Gestão; Arquivo Público do Estado do Rio Grande do Sul (APERS), 2021.

SEMLEY, L. Writing the History of the Trans-African Woman in the Revolutionary French Atlantic. In: CANDIDO, M. P.; JONES, A. African women in the Atlantic world: property, vulnerability \& mobility, 1660-1880. New Edition ed; Boydell \& Brewer, 2019. p. 191-216.

SILVA, F. R. A Inquisição em Cabo Verde, Guiné e S. Tomé e Príncipe (1536 1821): contributo para o estudo da política do Santo Ofício nos territórios africanos. Dissertação (Mestrado em História dos Descobrimentos e da Expansão Portuguesa - Séculos XV a XVIII), Universidade Nova de Lisboa, Lisboa, 2002.

SILVA, F. R. A Inquisição na Guiné, nas ilhas de Cabo Verde e São Tomé e Príncipe. Revista Lusófona de Ciência das Religiöes, n. 5-6, p. 157-173, 2004.

SILVA-SANTOS, V. Mulheres Africanas no Mundo Atlântico. Afro-Ásia, n. 64, 2021.

SIQUEIRA, S. A. Os Regimentos do Santo Ofício. Revista do IHGB, Rio de Janeiro, n. 392, 1996.

Data de submissão: 27/07/2021

Data de aprovação: 30/07/2021 